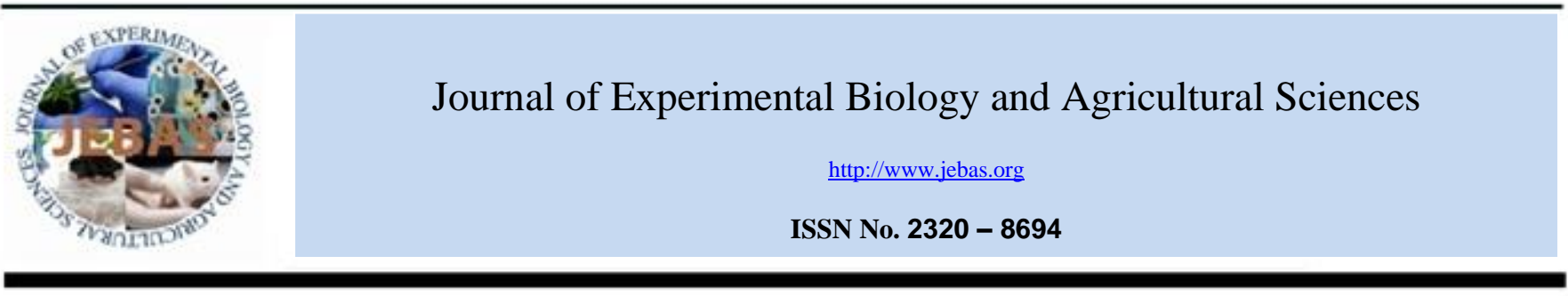

\title{
BIOTECHNOLOGICAL TOOLS FOR DIAGNOSIS OF EQUINE INFECTIOUS DISEASES
}

\section{Minakshi Prasad ${ }^{1, *}$, Basanti Brar ${ }^{1}$, Ikbal $^{1}$, Koushlesh Ranjan ${ }^{2}$, Upendra Lalmbe ${ }^{1}$, J. Manimegalai ${ }^{1}$, Bhavya Vashisht $^{1}$, Sandip Kumar Khurana ${ }^{4}$ and Gaya Prasad ${ }^{3}$}

${ }^{1}$ Department of Animal Biotechnology, LLR University of Veterinary and Animal Sciences, Hisar, Haryana, India, 125004

${ }^{2}$ Department of Veterinary Physiology and Biochemistry, Sardar Vallabhbhai Patel University of Agriculture and Technology, Meerut, India, 250110

${ }^{3}$ Sardar Vallabhbhai Patel University of Agriculture and Technology, Meerut, Uttar Pradesh, India, 250110

${ }^{4}$ NRCE, Hisar, Haryana, India, 125001

Received - November 05, 2016; Revision - November 20, 2016; Accepted - December 04, 2016

Available Online - December 04, 2016

DOI: http://dx.doi.org/10.18006/2016.4(Spl-4-EHIDZ).S161.S181

\section{KEYWORDS \\ Biotechnology \\ Immunoassay \\ Equine}

Infectious disease

\begin{abstract}
Rapid diagnosis of infectious diseases and appropriate treatment with in time are important steps that promote optimal clinical outcomes and general public health. Today there is large number of new technologies such as nanotechnology, biosensors, and microarray techniques, are being developed and used as diagnostic tools for equine infectious diseases. Nucleic acid based techniques such as polymerase chain reaction (PCR) have become conventional tools in veterinary research and plays an important role in specific typing determinations as well as for rapid screening of ample numbers of samples at the time of equine disease outbreaks. Other biotechnological techniques are populous to be used in the coming times as they can enhance diagnostic efficacy in less time and cost as compared to conventional techniques. This review focuses on biotechnological tools available for equine diseases diagnosis and its applications hold great promise for improving the speed and accuracy of diagnostics for equine infectious diseases.
\end{abstract}

* Corresponding author

E-mail: minakshi.abt@gmail.com (Minakshi Prasad)

Peer review under responsibility of Journal of Experimental Biology and Agricultural Sciences.

Production and Hosting by Horizon Publisher India [HPI] (http://www.horizonpublisherindia.in/).

All rights reserved
All the article published by Journal of Experimental Biology and Agricultural Sciences is licensed under a Creative Commons Attribution-NonCommercial 4.0 International License Based on a work at www.jebas.org.

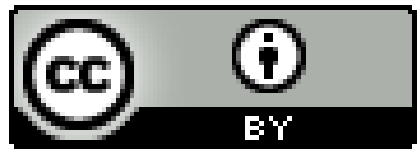




\section{Introduction}

Modern molecular biology provides us newer technology to diagnose and control several equine diseases. It is also used for the development of novel diagnostic tools for equine infectious disease control (Pusterla et al., 2006; Amaya, 2014). Several diagnostic tools such as nucleic acid probes, monoclonal antibodies, restriction fragment length polymorphisms, real time PCR, proteomics, biosensors and nanotechnology have increased the livestock productivity. These methods have been commonly used for equine disease diagnosis and control (Yeh et al., 2010; Johnson et al., 2010; Rakhshandehroo et al., 2014). Several viral and bacterial pathogens such as Japanese encephalitis virus, West Nile virus, Hendra virus, borna virus, equine rabies, Rhodococcus equi, Bacillus anthracis etc., are causes several serious diseases in equines and induce economic to human population and these are zoonotic in nature (Yeh et al., 2010; Booth et al., 2010; Priestnall et al., 2011; Khurana, 2015).

On various occasion equines are used for various purposes such as ceremonies, riding, sports, draught racing, transport and antitoxin/antibody production, throughout the world (Burnouf et al., 2004). There is possibility of disease transmission and spread at the time of equines movement from one country to another. Therefore, OIE (World Organisation for Animal Health) has enlisted several diagnostic tests for international movement of equines (Table 1) (OIE, 2016). Biotechnology may play an important role in prevention of disease caused by these pathogens.

The correct knowledge of molecular biology of infectious agents and their hosts is very important for controlling the disease (Tavares et al., 2011). Biotechnological and protein based assays can play a main role in equine disease control due to its everlasting developments with the use of developed anti pathogenic drugs and diagnostic chemicals. Even though conventional techniques are still used commonly, recent biotechnological assays have widened the scope of equine diseases detection and give us powerful new techniques for quick and specific identification of equine diseases. This manuscript reviews the current and potential uses of biotechnology tools for equine infectious disease diagnostics.

\section{Serological assays}

Protein based assays are based on antibody and antigen interaction. These types of several assays such as enzyme linked immunosorbent assay (ELISA), falcon assay screening test-ELISA, indirect or direct immunofluroscencent antibody tests, immunoblotting dot-ELISA, peptide based-ELISA, complement fixation test, agar gel immunodiffusion and neutralization test are used for equine infectious disease diagnosis. These serological assays are highly sensitive and specific than other techniques like microscopy and it allow clearance of post-therapeutic pathogen.

\subsection{Enzyme-linked immunosorbant assay (ELISA)}

Components of immune system used for detection of immune response against infection in ELISA test. For detection of specific immune response, ELISA assay involves antigen, antibody and enzymes. The antigens are adhered to surface of microtitre plate and antibody specific to the antigen is applied over the surface for binding. It was followed by the conjugation of antibody with an enzyme-Horseradish peroxidise. Further, substrate was added to the plate for producing visible colour change in a reaction mixture. Based on use or not of a secondary antibody, the ELISA test may be either direct or indirect (Figure 1). This test is successfully used for diagnosis of various diseases in equines. Singha et al. (2014) have reported an indirect ELISA using truncated TssB protein for serodiagnosis of glanders.

A sensitive antigen capture ELISA was developed for the detection of secreted NS1 from infected equines with West Nile virus (Macdonald et al., 2005; Chung \& Diamond, 2008). Similarly, ELISA has been developed for the detection of EHV-1, EHV-4 (Yasunaga et al., 2000), equine rhinitis virus A (ERAV) (Kriegshauser et al., 2009) and equine rhinitis virus B (ERBV) (Kriegshauser et al., 2008). In the recent studies, ELISA targeting antibodies to the spike (S) of equine corona virus was developed and validated to detect antibodies to EqCoV in infected horses (Kooijman et al., 2016).

Table 1 Prescribed test for equine diseases according to OIE, 2016.

\begin{tabular}{|ll|}
\hline Disease name & OIE prescribed tests \\
\hline African horse sickness & CF, ELISA \\
\hline Contagious equine metritis & Agent identification. \\
\hline Dourine & CF \\
\hline Equine infectious anaemia & AGID \\
\hline Equine piroplasmosis & ELISA, IFA \\
\hline Equine viral arteritis & Agent identification (semen only), Virus Neutralization \\
\hline Glanders & Complement Fixation \\
\hline
\end{tabular}



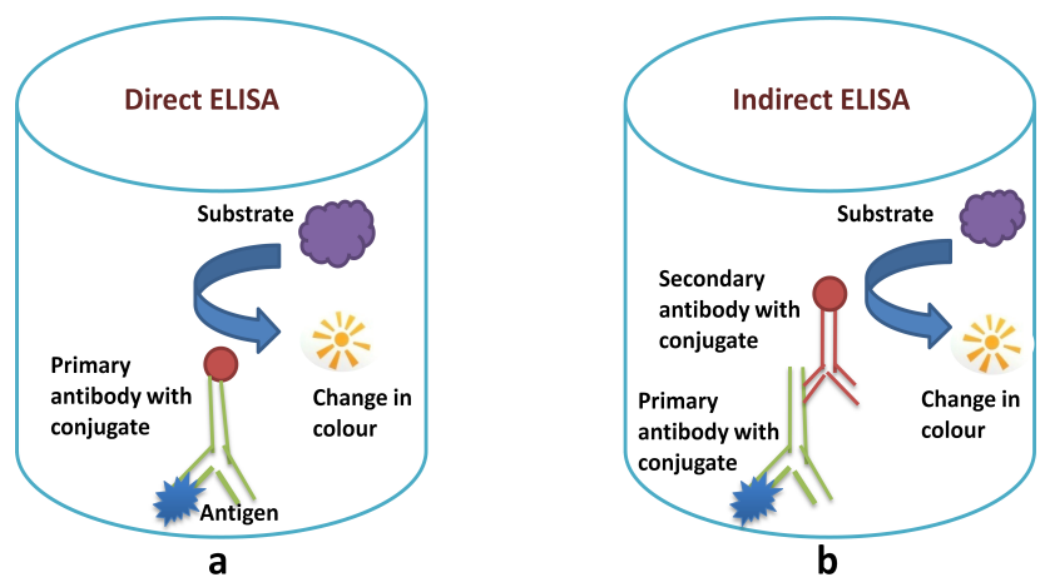

Figure 1 Principle of ELISA test a) Direct ELISA b) Indirect ELISA

\subsection{Dot-ELISA}

Dot-ELISA works on the basis of attachment of small amount of antigen on to a nitrocellulose membrane. Specific antibody is incubated with antigen containing dotted membrane followed by adding of enzyme conjugated anti-antibody. A substrate is added in the last which causes precipitation of a detectable coloured dot on the membrane (Svobodova et al., 2013). It was reported that the dot-ELISA is simple, quick, specific, sensitive, low cost field test that detects minute levels of antibodies much faster than complement fixation test and indirect hemagglutination antibody test (Verma \& Misra, 1989; Verma et al., 1990). Dot-ELISA has been used for the serodiagnosis of glanders (John et al., 2010). By the use of nitrocellulose membrane in this test makes it applicable in the field. This assay is quick and specific in detection of various diseases. It gives us low background as compared to ELISA assay that can easily differentiate between the positive and negative samples.

\subsection{Fluorescent Antibody Test (FAT)}

In Fat assay, antibody is labelled with fluorescent dye, is used in visualization of antigen in a clinical specimens. The antibody conjugated with fluorescent dye and antigen-antibody complex gives a visible glow sign when examined under a fluorescent microscope. The fluorescent dye can be tagged directly with primary antibody which is known as direct fluorescent antibody test or with a secondary anti-antibody known as Indirect Fluorescent Antibody Test (Figure 2). The FAT is used in diagnosis of several equine diseases. This assay was recently investigated for diagnosis of equine leptospiral abortion in mare (Erol et al., 2015). The sarcocystis neurona causes a dreadful disease, equine protozoal myeloencephalitis (EPM) in equines. The IFAT was successfully validated for CSF testing for confirmation of EPM in equines (Duarte et al., 2006; Johnson et al., 2013).
The overall specificity and accuracy of IFAT was shown to be better than that of the western blot and modified western blot, which showed its potential to use as a diagnostic assay for detection of EPM caused by Sarcocystis neurona (Duarte et al., 2003). The FAT and immune-histo-chemistry (IHC) assay confirmed the presence of Australian bat lyssa virus (ABLV) antigen in horse brain tissues (Shinwari et al., 2014). A FAT assay has been used for the direct identification of bacterial Helicobacter on the equine gastric mucosa (Perkins et al., 2012). This technique has been used to describe the spatial distribution of Helicobacter species in the stomach of healthy horses to demonstrate the microbiota of normal appearing squamous and glandular mucosa (Burton et al., 2007).

\subsection{Complement Fixation Test}

Complement fixation test (CFT) is an immunological test used for detection of presence of either antigen or antibody in the serum sample. It was generally used for microorganisms which are not easily cultured in research laboratory (Figure 3). Although, several studies have revealed its low specificity and sensitivity for virus detection, it is still used for many equine viral disease diagnoses. CFT is the OIE recommended test for glanders. Due to low prevalence of glanders in equine population it is important to use test with high specificity and sensitivity. CFT was found reproducible and reliable assay for clinical investigation and detection of latent infection of Equine herpes virus 1 (EHV1) (Hartley et al., 2005). A CFT assay has some limitations such as laborious, time consuming and often cross reactivity in nature. The non-specific hemolysis of RBC can be prevented using Potassium Periodate $\left(\mathrm{KIO}_{4}\right)$. The $\mathrm{KIO}_{4}$ treatment to horse sera prevented the non-specific hemolysis which helped in determination of precise titers during CF test for EHV-1 diagnosis (Bannai et al., 2013). The CFT and virus neutralisation assays were used for determination of sero-conversion of EHV1 and EHV4 during obtaining acute and convalescent serum samples (Hartley et al., 2005). 


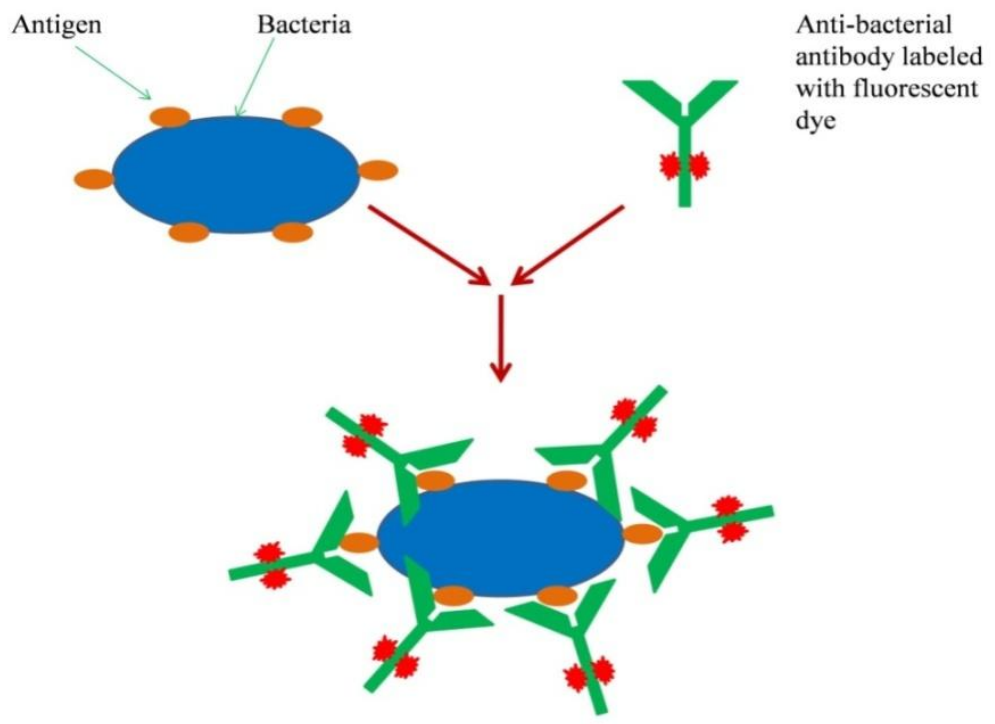

Figure 2 Principle of Direct Fluorescent antibody test (FAT).

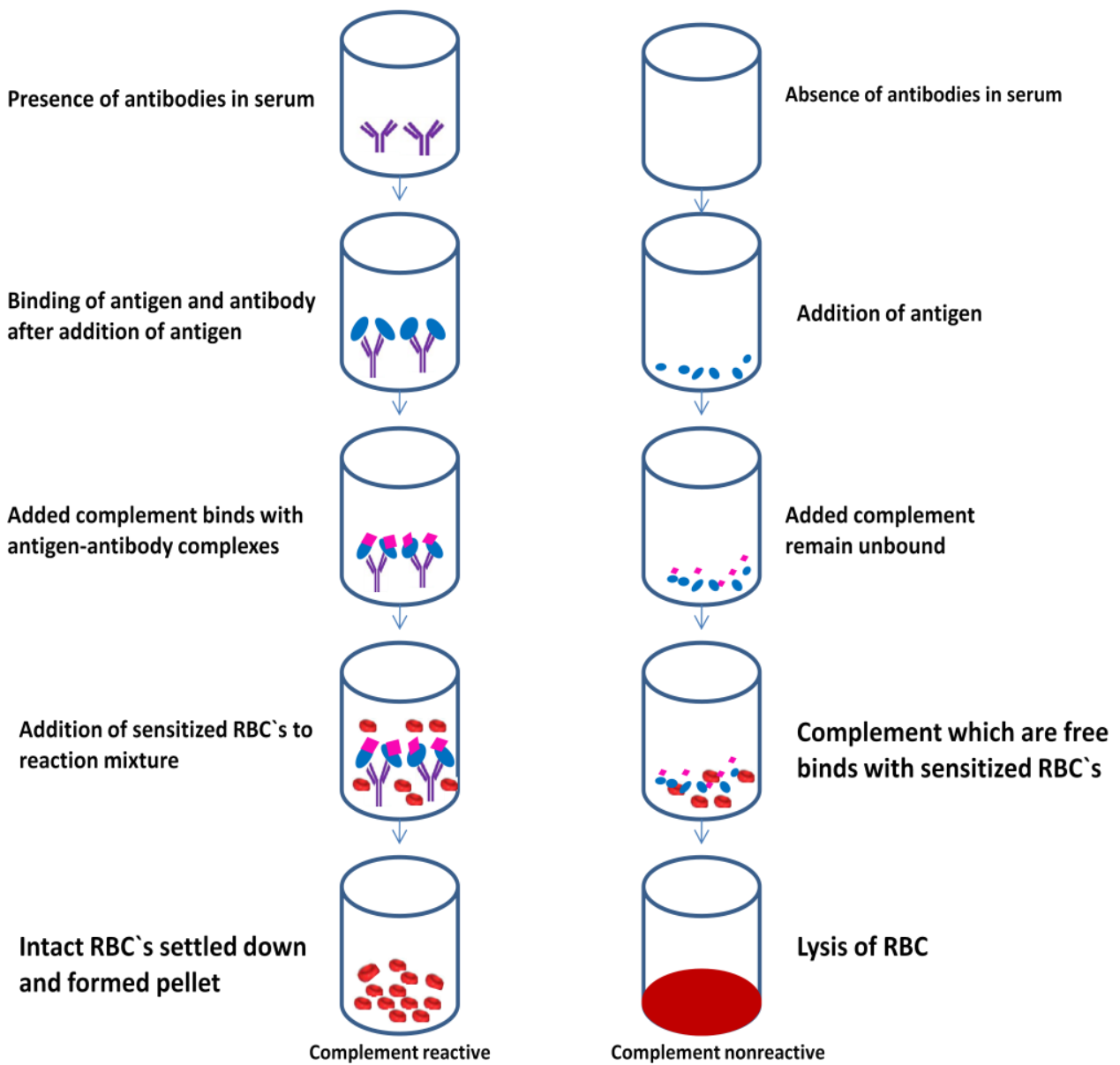

Figure 3 Complement fixation test. 


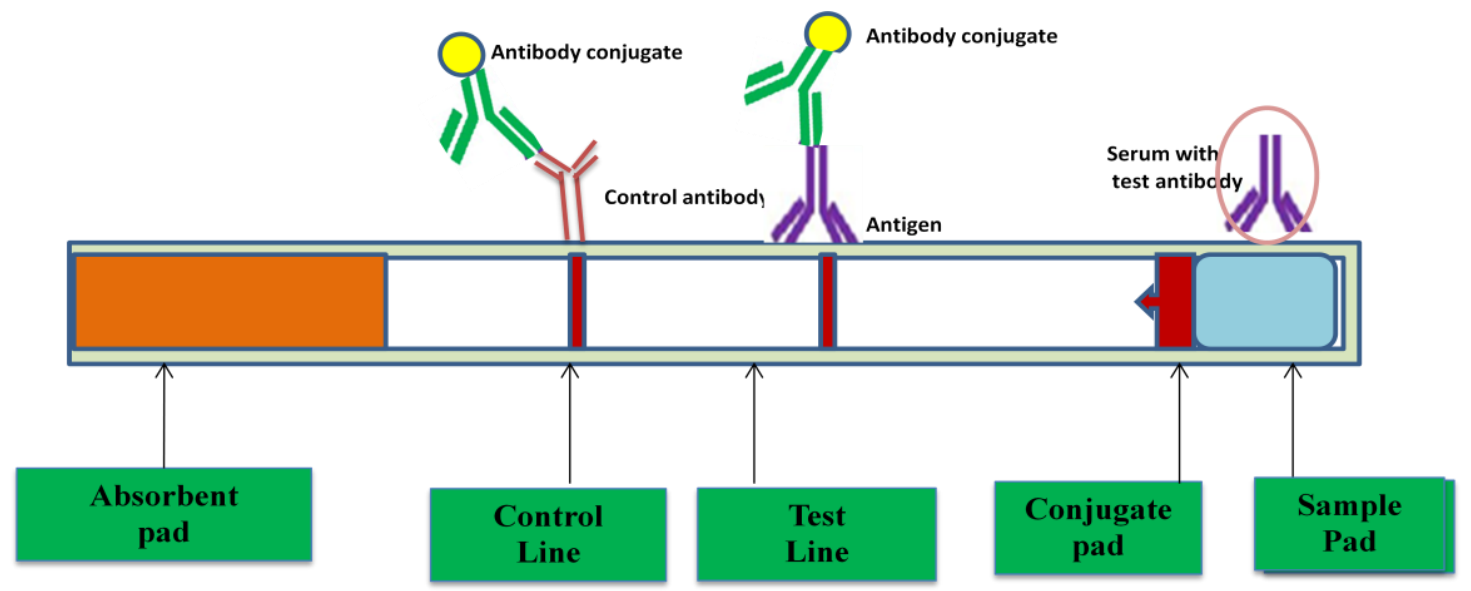

Figure 4 Principle of lateral flow test

\subsection{Lateral Flow Test (LFT)}

This test is also known as a lateral flow immunochromatographic strip assay. LFT is used as diagnostic techniques in medical and veterinary applications. It is an easy and fast assay used for identification of interest target in sample without using any special equipment (Figure 4). This technique can be used for qualitative or specific semiquantitative identification of many interest targets such as antibodies, antigens and nucleic acid products. The assay indicates a procedural control line which shows that the assay was performed properly and validates the test result. Therefore, presence of two lines gives positive result, while indication of only control line shows negative test in experiment. However, the appearance of no lines or only test line shows invalid result and test must be repeated. This test has been successfully used in diagnosis and detection of various disease associated with equines from biological samples. The recombinant viral capsid protein p26 conjugated to colloidal gold based simple immunochromatographic lateral flow (ICLF) test was validated for specific detection of Equine infectious anemia virus (EIAV) antibodies in equine sera (Alvarez et al., 2010). Similarly, LFT was also used for detection of vesicular stomatitis virus in cattle and horse clinical samples (Ferris et al., 2012).

\subsection{Virus neutralization test}

In virus neutralization tests, serial dilutions of heat inactivated test serum are prepared and poured in a 96 well plate and are incubated with a defined amount (generally 100 TCID 50) of infectious virus (antigen). After incubation time period, susceptible virus cells are added to the virus-serum mixture and the final serum, virus and cell combination is kept for period of 2-3 days. Depending on the virus, this may be done by microscopic examination of the plate for the indication of viral cytopathic effect (CPE). Serum containing antibodies specific to the virus in target are capable to neutralize the aliquot of virus used in the test line, hence preventing the infection of cells when added to the plate. At the time of very high concentrations of antibody to the virus in target are present in the test sample, virus neutralization will be occur at high serum dilutions. Whenever, where some or no antibody to the virus is present in the serum sample, it will be able to neutralize the infectious virus at the first dilution used in the test. The result of the test is the target at which the serum sample has been diluted such that it no further neutralizes the entire virus in the test. This dilution indicates the titre of the serum tested. The sero-prevalence of EHV-1 and EHV-9 infections was reported by serum neutralization test (Borchers et al., 2005; Taniguchi et al., 2000).

\subsection{Agar Gel Immunodiffusion (AGID)}

AGID technique is used for the detection, identification and quantification of antibodies and antigens present in biological samples. In this technique, a gel plate is cut to form a series of wells in agar gel. A sample aliquot of interest target is placed in one well, and antibodies are placed in nearby well and the plate was incubated for 48 hours. During incubation time the antigens in the target sample and the antibodies each diffuse out from their corresponding wells. At the point where the two diffusion lines intersect, if any of the antibodies is specific to any of the antigens then they will bind to each other and form a complex. This antigen-antibody complex precipitated gives a thin white line in the gel, helps in the visual identification of antigen recognition. AGID can be used to diagnose Equine Infectious Anemia (EIA) (Beltrao et al., 2015). It detects antibodies against the main capsid viral protein (p26) in horse serum samples and this test is simple, inexpensive and specific to identify EIAV-infected animals (Alvarez et al., 2010).

\subsection{Peptide based-ELISA}

Petide based-ELISA, a plate based techniques for detecting and quantifying peptides, proteins, hormones and antibodies. In this technique, a synthetic peptide is to be mobilized onto a solid support and complexes with an antibody, linked to an 
enzyme. Detection is done by assessing the conjugated enzyme activity after incubation with a substrate to produce a measurable end product (Figure 5). The very important step for the detection strategy is a specific antigen-antibody interaction. Peptide-ELISAs are performed in a 96-well microtiter plate with synthetic peptide in carbonate buffer followed by incubating the plate overnight at $4^{\circ} \mathrm{C}$. Now, block the plate with blocking buffer for 1 hour at $37^{\circ} \mathrm{C}$ followed by addition of freshly prepared diluted primary antibody into each wells and incubate the plate at $37^{\circ} \mathrm{C}$ for 1 hour. Subsequently, antimouse IgG, diluted in $100 \mu \mathrm{l} /$ well antibody dilution buffer is added with the incubation at $37^{\circ} \mathrm{C}$ for 30 minutes. In last enhancement solution is added in the plate and incubated at $37^{\circ} \mathrm{C}$ for 15 minutes. The plate was washed in between each step at least five times with 1X PBST. Read the absorbance at appropriate wavelength with an appropriate time resolved plate reader.
Soutullo et al. (2001) evaluated the performance of an equine infectious an Aemia-ELISA designed with synthetic peptides. This assay could be important to prove for large throughput screening and early detection of equine infectious anaemia (EIA), when the results of the traditional Coggins test are still negative. Recently, a sensitive and specific peptide-based ELISA was developed to determine the sero-prevalance of EHV-1 and EHV-9 (Abdelgawad et al., 2015). For discrimination between serological responses to EHV 1 and EHV4 immunoglobulins-IgG based type specific ELISA was developed (Ma et al., 2013). This technique was also used to discriminate between EHV-1 and EHV-4 glycoprotein E peptides for EHV-1 and glycoprotein $\mathrm{G}(\mathrm{gG})$ for EHV-4 (Lang et al., 2013; Yasunaga et al., 1998). Recently, a glycoprotein G based peptide ELISA was developed for detection of equine herpesvirus type 4 (Bannai et al., 2016).
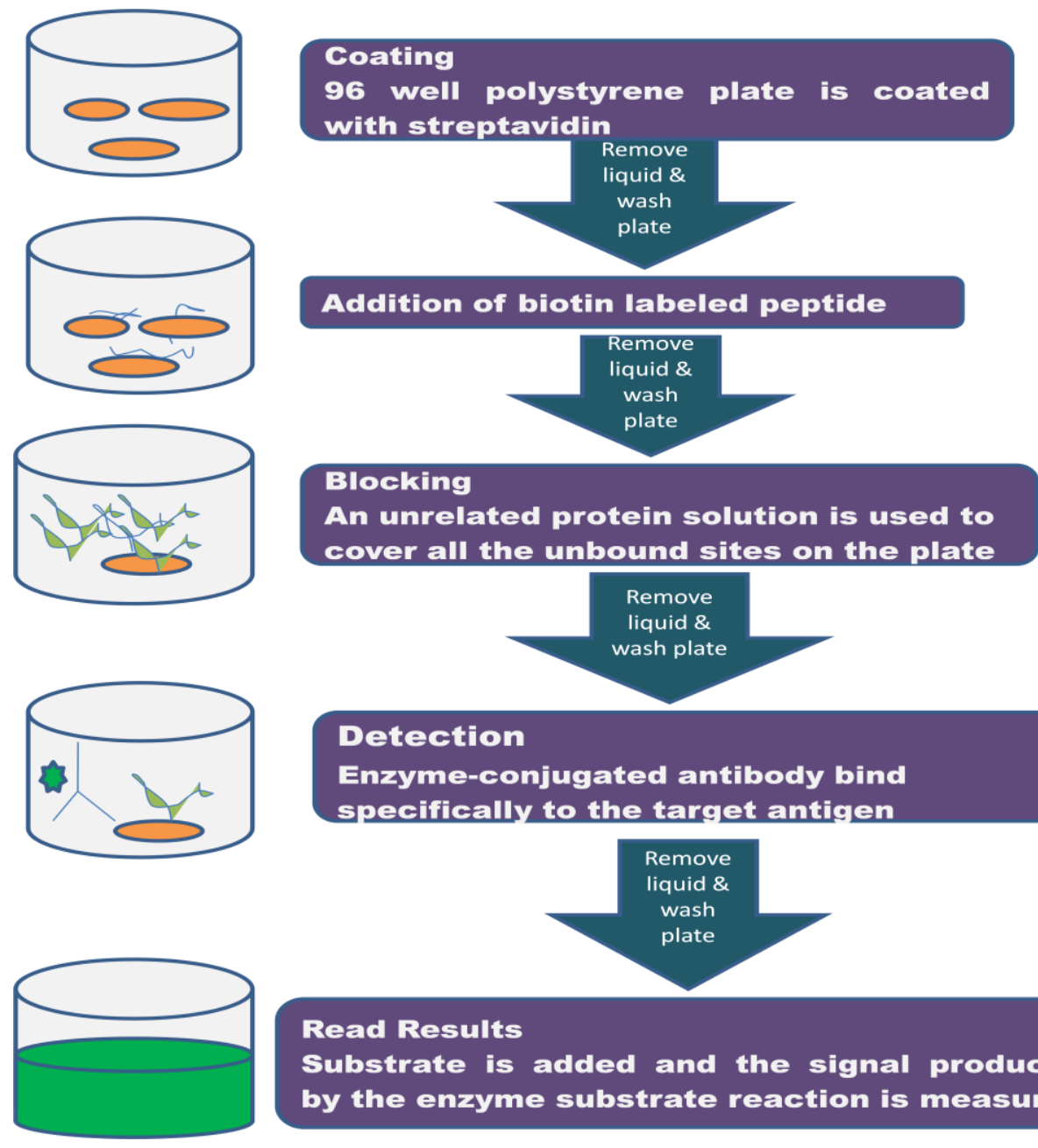

Detection

Enzyme-conjugated antibody bind

specifically to the target antigen

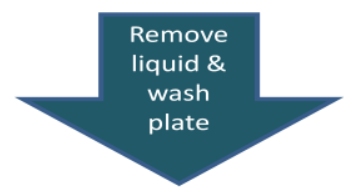

Read Results

Substrate is added and the signal produced by the enzyme substrate reaction is measured

Figure 5 Principle of peptide- ELISA 


\subsection{Nucleic acid diagnostics}

Nucleic acid-based detection methods including polymerase chain reaction, reverse transcriptase-PCR, nested-PCR, restriction fragment length polymorphism, amplified fragment length polymorphism, random amplified polymorphic DNA, loop-mediated isothermal amplification, microarray, real-time PCR are used for identification of several equine diseases (Pusterla et al., 2007; Monego et al., 2009; Yeh et al., 2012; Quereda et al., 2000; Larrasa et al., 2002; Eischeid, 2011).

\subsection{Polymerase Chain Reaction (PCR)}

PCR uses the enzyme DNA polymerase that amplifies a small length of targeted DNA using primers which are specific to the target. It will amplify the selected target sequence from a mixture of genome. PCR acts as an important tool for the identification of parasites due to the insufficient amount of availability of antigen and antigen products by using conventional assays (Gasser, 2006). PCR can utilize almost all kind of biological samples such as meat, blood, urine, skin scrapings and faeces for parasitic infection study. When compared to the conventional method the detection limit of PCR is higher.

Therefore, it is useful for detecting low amount of antigen in suspected samples (Varrasso et al., 2001; Nugent et al., 2006). It can also be used for detection of many equine diseases (Oldfield et al., 2004; Ocampo-Sosa et al., 2007; Pusterla et al., 2007; Letek et al., 2008; Monego et al., 2009). Polymerase chain reaction (PCR)-based diagnostic tests can allow rapid and sensitive detection of equine infectious pathogen (Paxson, 2008). Yeh et al. (2010) developed a duplex reverse transcriptse PCR which is sensitive, specific and very rapid and is useful in both humans and as well as in horses for the simultaneous and differential diagnosis of West Nile and Japanese encephalitis viruses.

Table 2 PCR testing results for a variety of infectious equine pathogens.

\begin{tabular}{|c|c|c|}
\hline Pathogen & PCR test & References \\
\hline West Nile Virus & RT-nPCR & Johnson et al. (2001) \\
\hline $\begin{array}{l}\text { Strongylus edentatus, Strongylus equinus and Strongylus } \\
\text { vulgaris }\end{array}$ & PCR-RLB & Traversa et al. (2007) \\
\hline Herpes viruses 4 and 1 & PCR & Brendan \& Michael (1993) \\
\hline Equine herpesvirus 1 and 4 & Differential multiplex PCR & Carvalho et al. (2000) \\
\hline Distinguish between EHV-1 and EHV-4 & PCR & Wagner et al. (1992) \\
\hline EHV1, EHV4, EHV2 and EHV5 & Multiplex PCR & Wang et al. (2007) \\
\hline Rhodococcus equi & PCR & $\begin{array}{l}\text { Khurana et al. (2015); Pal \& } \\
\text { Rahman, (2015) }\end{array}$ \\
\hline Rhodococcus equi & Multiplex PCR & Chhabra et al. (2015) \\
\hline Equine arteritis virus & RT-PCR & $\begin{array}{l}\text { St-Laurent et al. (1994); Zhang } \\
\text { et al. (2008) }\end{array}$ \\
\hline Theileria equi & $\begin{array}{l}\text { Nested PCR and Nested PCR with } \\
\text { hybridisation }\end{array}$ & Wise et al. (2013) \\
\hline Babesia caballi & Nested PCR & Battsetseg et al. (2001) \\
\hline Babesia equi & Nested PCR & Battsetseg et al. (2001) \\
\hline Streptococcus equi & PCR & Ijaz et al. (2012) \\
\hline Equine influenza virus & RT-PCR & OIE, (2016) \\
\hline Leptospira spp. & PCR & Faber et al. (2000) \\
\hline Salmonella spp. & PCR & Amavisit et al. (2001) \\
\hline Alternaria spp. & PCR & Dicken et al. (2010) \\
\hline Emmonsia crescens & Single step PCR & Pusterla et al. (2002) \\
\hline Lawsonia intracellularis & Faecal PCR & Lavoie et al. (2000) \\
\hline Corynebacterium pseudotuberculosis & Real-time PCR/ RAPD-PCR & Foley et al. (2004) \\
\hline Anaplasma phagocytophilum & $\mathrm{nPCR}$ & $\begin{array}{l}\text { Lee et al. (2015); } \\
\text { M'ghirbi et al. (2012) }\end{array}$ \\
\hline Streptococcus equi & Species-specific PCR & Javed et al. (2016) \\
\hline Equine encephalitis virus & RT-PCR & Linssen et al. (2000) \\
\hline Differentiation of B. malle $i$ and B.pseudomallei & Multiplex qPCR & Janse et al. (2013) \\
\hline Streptococcus equi & Triplex quantitative PCR & Webb et al. (2013) \\
\hline
\end{tabular}


Table 3 Examples of Real-time Polymerase chain reaction for the diagnosis of equine infectious pathogens.

\begin{tabular}{|lll|}
\hline Pathogen & Target gene & Reference \\
\hline Streptococcus equi & eqbE and SEQ2190 & Webb et al. (2013) \\
\hline Salmonella & ompC gene of S. Heidelberg & Amavisit et al. (2001) \\
\hline Salmonella spp, & invA gene & Pusterla et al. (2010) \\
\hline Anaplasma phagocytophilum & 16S rRNA & M'ghirbi et al. (2012) \\
\hline Streptococcus & 16S rRNA & Javed et al. (2016) \\
\hline Streptococcus equi & SeM gene & Javed et al. (2016) \\
\hline Streptococcus equi & sodA gene & Javed et al. (2016) \\
\hline Leptospira & ligA and B & Palaniappan et al. (2005) \\
\hline Corynebacterium pseudotuberculosis & PLD exotoxin gene & Spier et al. (2004) \\
\hline Equine arteritis virus & EAV ORF7 gene & Balasuriya et al. (2002) \\
\hline Equine herpes virus 1 & Glycoprotein B & Diallo et al. (2006) \\
\hline Equine herpes virus 4 & Glycoprotein B & Diallo et al. (2007) \\
\hline Equine herpes virus 1 & gD and IR6 gene & Goodman et al. (2007) \\
\hline Strongylus vulgaris & rDNA & Nielsen et al. (2008) \\
\hline Equine Influenza Virus & Matrix and hemagglutinin gene & Quinlivan et al. (2005) \\
\hline Pseudomonas syringae pv. aesculi & Gyrase B & Green et al. (2009) \\
\hline Lawsonia intracellularis & Aspartate ammonia lyase gene & Pusterla et al. (2008) \\
\hline Theileria equi & 18S rRNA & Kim et al. (2008) \\
\hline Equine infectious anemia virus & gag gene & Cook et al. (2002) \\
\hline African horse sickness & NS1 & Rodriguez-Sanchez et al. (2008) \\
\hline Babesia equi & ema-1 gene & Ueti et al. (2005) \\
\hline Corynebacterium pseudotuberculosis & Phospholipase D gene & Sharon et al. (2004) \\
\hline Burkholderia mallei & ISBma2 & Janse et al. (2013) \\
\hline
\end{tabular}

Further, Yeh et al. (2012) developed a diagnostic algorithm which serologically differentiates West Nile virus from Japanese encephalitis virus infection and its validation in field surveillance of horses. Rakhshandehroo et al. (2014) had done an intra-specific variation study for Habronema muscae in horses using cytochrome c oxidase subunit 1 gene based identification by PCR technique. Helicobacter bacterium infection was reported by Contreras et al. (2007) using the16S rRNA gene specific PCR in equines.

PCR can also be combined with other molecular methods such as reverse transcriptase or nested PCR to genotype the organisms. RT-PCR has also been developed for Western Equine Encephalitis Virus (WEEV) diagnosis (Linssen et al., 2000; Lambert et al., 2003). RT-PCR assay was successfully used for identification of west nile and japanease encephalitis virus (Lanciotti \& Kerst, 2001). A multiplex PCR was designed to amplify herpes simplex virus types 1 and 2, cytomegalovirus, and varicella-zoster virus DNA present in a diverse range of clinical material (Druce et al., 2002). Multiplex PCR assays for the simultaneous identification of varicella zoster virus (VZV), herpes simplex viruses (HSV), CMV, human herpesvirus 6, and Epstein-Barr virus in cerebrospinal fluid (Quereda et al., 2000) and assays for HSV and VZV in mucocutaneous specimens (Jain et al., 2001; Nogueira et al., 2000) and CSF (Read \& Kurtz, 1999) have been reported, each with improved utility over existing methods in the diagnostic setting. In a recent study herpesvirus (EHV) type 1 was detected using PCR and neuropathogenic genotype of EHV-1 was identified by DNA sequencing
(McFadden et al., 2016). Various types of PCR are used for testing a Variety of Infectious Equine Pathogens (Table 2).

\subsection{Random Amplified Polymorphic DNA (RAPD)}

It is a type of PCR reaction which amplifies segments of DNA randomly. It uses short primers of nucleotide length varies from 8-12 nucleotides and template DNA for PCR amplification. By resolving the resulted amplified product on agarose gel electrophoresis a semi unique profile pattern can be visualized from a RAPD reaction. Although RAPD is comparatively easy to perform, but it is also a PCR dependent assay so it needs specific PCR protocol to give reproducible result. Any kind of mismatch in template and primer results in complete absence of PCR product and makes it difficult to interpret the results of RAPD. This assay has the potential to play a useful role in genetic analyses of livestock species such as horses (Cushwa \& Medrano, 1996). Larrasa et al. (2002) described the development of quick and relevant DNA extraction and RAPD methods that can be used for genotyping Dermatophilus congolensis field isolates. Larrasa et al. (2004) reported the molecular typing of $D$. congolensis from horse skin sample by RAPD and pulsed field gel electrophoresis (PFGE) techniques.

\subsection{Real time PCR}

The real-time PCR assay gives us the quantification of several types of biological samples using verities of fluorescent materials such as TaqMan probes, SYBR Green dye and 
Scorpion primers (Nado, 2009). The pathogenic nucleic acids from various biological and environmental samples can be quantified to give the information about the extent of infection. The SYBR Green dye based Real-time PCR assays have been validated for many equine diseases from several decades. Table 3 presents an overview of real-time PCR routinely used for the detection of equine pathogens such as bacterial, viral and parasitic pathogens. Although Real-time PCR is excellent in showing sensitive and specific results but it is still uncommon in routine laboratory diagnosis especially in rural endemic areas due to its sophistication. In the Real-time amplification protocols, other procedures such as DNA extraction, choice of primers may cause heterogeneity in results and causes difficulty in standardization of assay (Bretagne \& Costa, 2006).

A SYBR Green based assay was developed that could detect $100 \%$ of the different WNV target region variants in their study, whereas a TaqMan assay failed to detect $47 \%$ of possible single nucleotide variations in the probe-binding site (Papin et al., 2004). Johnson et al. (2010) designed a panflavivirus RT-PCR using degenerate primers for the NS5 gene to allow the detection of a range of flaviviruses including WNV. This SYBR Green based RT-PCR was able to detect the WNV however the sensitivity was much lower compared to WNV-specific TaqMan RT-PCR assays (Johnson et al., 2010). SYBR Green has been shown to inhibit the PCR reaction to some extent and melt curve analysis is troublesome by dye redistribution during melting. Eischeid analyzed and reported about the behaviour of other DNA dyes in Real-time PCR and showed that EvaGreen and SYTO dyes out performed SYBR Green in real-time PCR (Eischeid, 2011).

\subsection{Probe Hybridization}

Fragments of DNA or RNA usually around 100-1000 bases length used to detect the presence of nucleotide sequences that are complementary to the probe sequence called hybridization probe and this probe hybridizes to single-stranded nucleic acid sequence (Wetmur, 1991). Due to the nucleotide base complementarily between the target and probe, the nucleotide sequence of probe allows pairing of probe and the target (Figure 6). The labelled probe is then hybridized to the target RNA (Northern blotting) or ssDNA (Southern blotting) immobilized on a membrane or in situ. The probe is tagged with a molecular marker of either radioactive (P32, I125 etc.) molecules or non-radioactive fluorescent molecules to detect the hybridization (Digoxigenin). The probe hybridization based assays have been used for diagnosis of equine infections such as equine arteritis virus (Balasuriya et al., 2002; Westcott et al., 2003). The probe hybridization assay is relatively easy to perform. EHV-1virus strain was reported by means of Southern blot and dot-blot hybridization (Morris \& Field, 1988). The probe hybridization assay was confirmed and the sensitivity was inferior to classical techniques such as virus isolation (Morris \& Field, 1988).

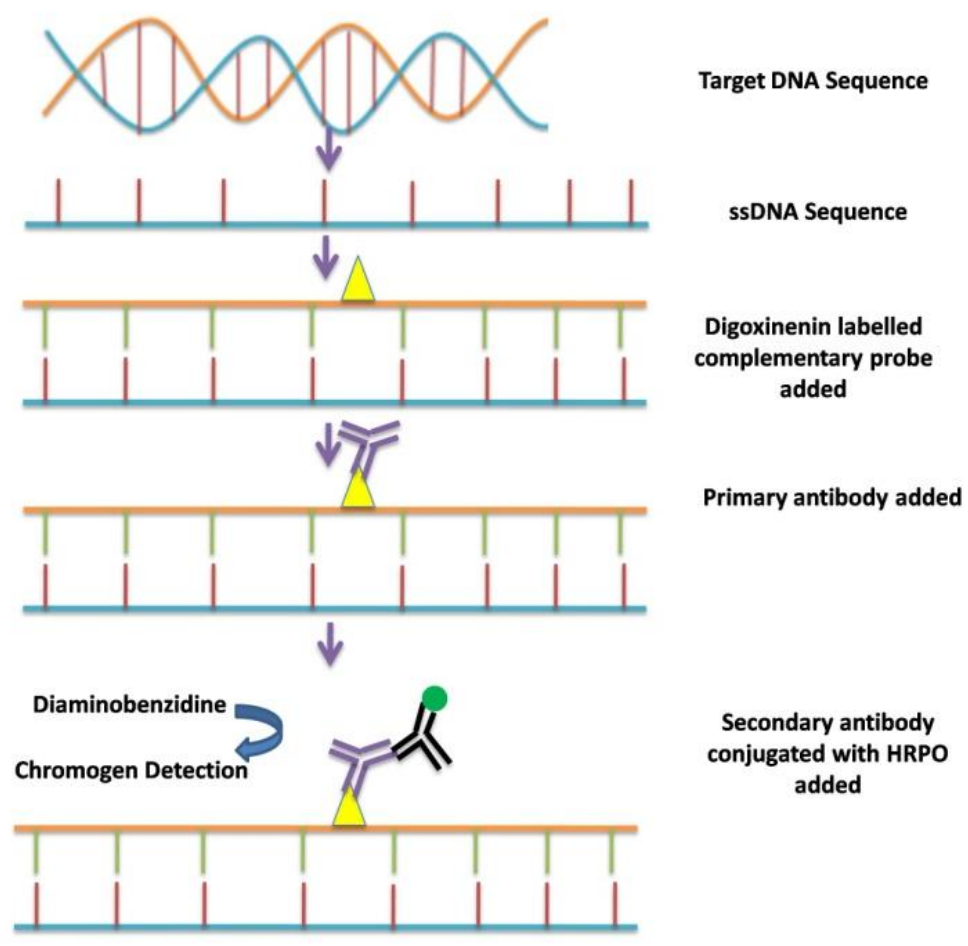

Figure 6 Principle of probe hybridization 
The nucleic acid microarray technique is a collection of microscopic nucleic acid spots attached to a solid glass surface. Picomoles of specific nucleic acid sequence are present on each spot called probe (Bumgarner, 2013). Probes are allowed to hybridize labelled target nucleic acid (cDNA or cRNA/antisense RNA). This probe-target hybridization can be detected and also can be quantified by silver, fluorophore or chemiluminescence-labeled targets (Figure 7). This technique is also used to measure the expression levels of many expressed genes of same or different species simultaneously. Microarray has also been used for diagnosis of equine disease detection. Equine-specific microarray has been used to estimate gene expression in laminitis (Noschka et al., 2009) and articular cartilage repair (Mienaltowski et al., 2009). A recent study using microarray technology on placental tissues identified a >900-fold upregulation of mRNA encoding the cytokine interleukin-22 in chorionic girdle, which is the first time IL-22 has been reported in any cells other than immune cells (Brosnahan et al., 2012). On the basis of whole genome single nucleotide polymorphism (SNP) analysis of all available Venezuelan equine encephalitis viruses (VEE) antigenic complex genomes, verifies that a SNP-based phylogeny accurately captured the features of the phylogenetic tree based on multiple sequence alignment, and reported a high resolution genome wide SNP (Gardener et al., 2016).

\subsection{Loop-mediated isothermal amplification (LAMP)}

LAMP is a nucleic acid amplification procedure that works under a unique amplification principle; involves two steps: these are cyclic or non-cyclic phase (Ushikubo, 2004; Parida et al., 2008).The non-cyclical step precedes the cyclical phase of amplification (Parida et al., 2008). It involves the four primers as well as the Bst DNA polymerase with strand displacement activity, play a role in this first stage of LAMP reaction. The cyclical step builds upon the product of the non-cyclical step which involves two outer primers along with the Bst DNA polymerase. The loop primers might be involved in the cyclic step when six primers are used (Nagamine et al., 2002). LAMP assay due to its unique properties has provided a powerful diagnosis of various pathogens (Notomi et al., 2000). LAMP technique amplifies nucleic acid at a very faster rate along with maintaining high specificity, sensitivity and efficiency (Parida et al., 2008). The most inventive feature of this technique is the simplicity of its protocol (Figure 8), and the low cost of overall amplification. Alhassan et al. (2007) developed a LAMP method for diagnosis of equine piroplasmosis.

Reverse transcription loop-mediated isothermal amplification (RT-LAMP) has been developed and it should be applicable to detect the equine rotavirus infection in molecular laboratories (Nemoto et al., 2010). Equine influenza virus was also reported using LAMP assay (Nemoto et al., 2011; Nemoto et al., 2012). Novel LAMP methods was developed specific to the pathogenic bacteria found in equine secondary pneumonia, namely, the Bacteroides-Prevotella group, Klebsiella pneumoniae, Stenotrophomonas maltophilia and Staphylococcus aureus (Kinoshita et al., 2015). Two different LAMP assays targeting Escherichia coli (Hill et al., 2008) or Pseudomonas aeruginosa (Goto et al., 2010) were used by Kinoshita et al. (2015), on clinical respiratory specimens and a high accordance was found between the results of the LAMP assays and bacterial culture. Use of these LAMP assays could enable rapid detection of pathogenic bacteria and swift administration of the appropriate antimicrobials. In this way, it is possible to concurrently perform LAMP assays to detect both the primary and secondary causative pathogens of lower respiratory bacterial infections in horses in only $60 \mathrm{~min}$ with the naked eye; this will make it possible to institute appropriate antimicrobial therapies more quickly in horses with secondary bacterial pneumonia (Kinoshita et al., 2015).

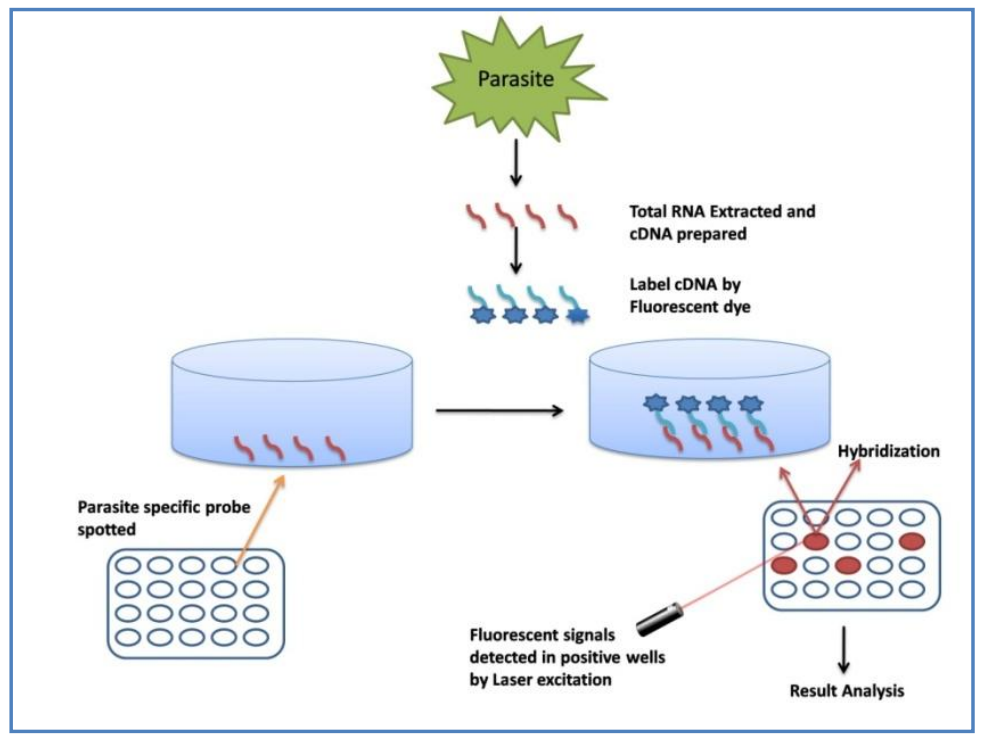

Figure 7 Principle of microarray assay. 

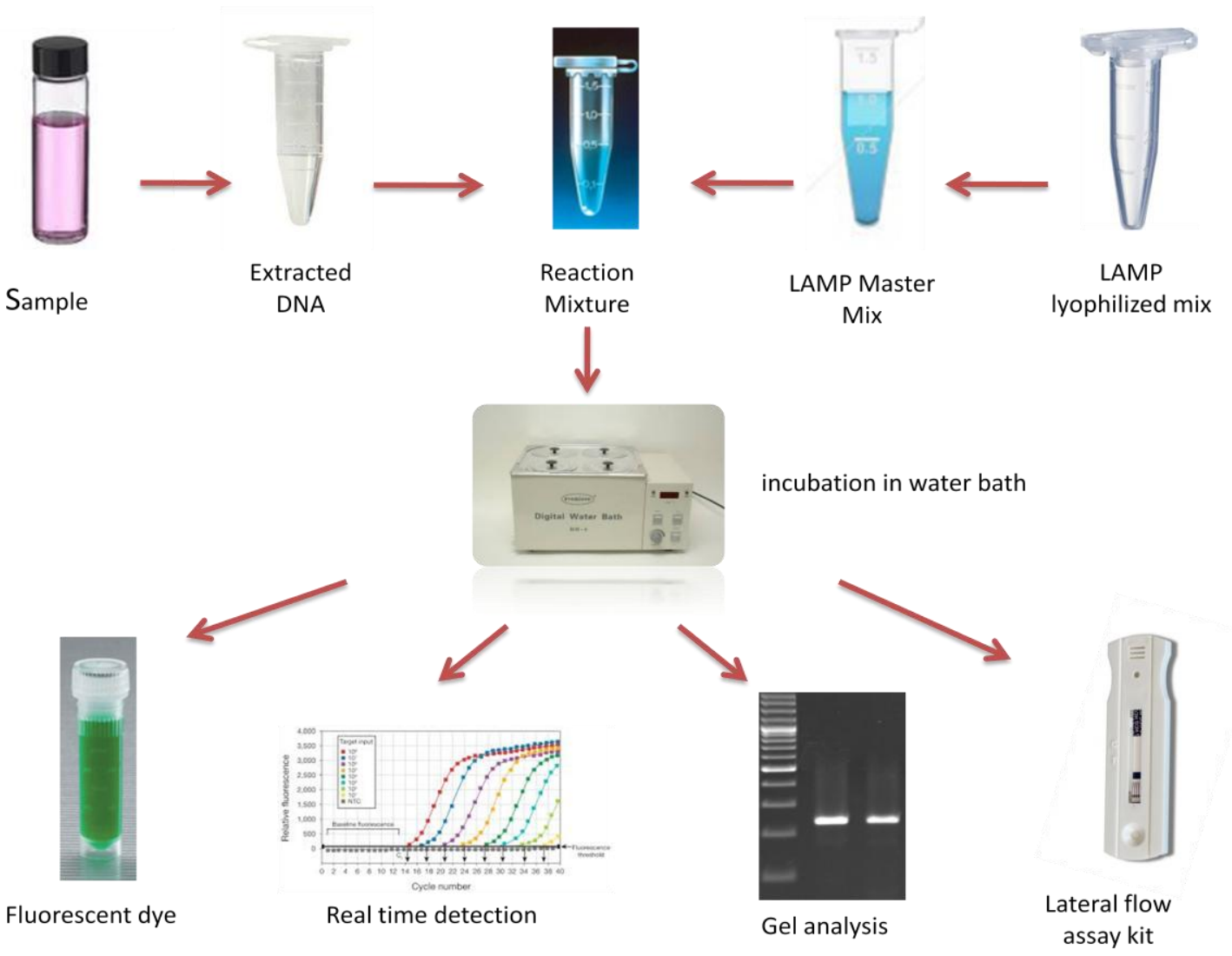

Figure 8 Principle of LAMP.

\subsection{Sequence analysis study}

Whole genome sequencing is a process that gives the complete DNA sequence of an organism's genome at a single time. High-throughput genome sequencing technologies have largely been used as a research tool and are currently being introduced in the clinics (Van et al., 2013; Gilissen, 2014; Nones et al., 2014). Genome sequencing of the domestic horse and subsequent advancements in the field of equine genomics have led to an explosion in the development of tools for mapping traits and diseases and evaluating gene expression (Finno \& Bannasch, 2014). In 2011, whole-genome sequencing of an individual American quarter horse mare was performed using massively parallel paired-end sequencing (Doan et al., 2012). Several single-gene disorders in quarter horses, such as polysaccharide storage myopathy (McCue et al., 2008; Tryon et al., 2009), hyperkalemic periodic paralysis, glycogen branching enzyme deficiency (Rudolph et al.,1992), and hereditary equine regional dermal asthenia (Ward et al., 2004; Finno et al., 2009) has been reported due to wholegenome sequencing of an individual American quarter horse mare. A high-quality draft assembly was constructed and additional sequence were provided by the inclusion of bacterial artificial chromosome end sequences from a related male thorough bred horse (Leeb et al., 2006). Kinoshita et al., (2014) reported the genera Bacteroides and Prevotella especially $B$. fragilis and $P$. heparinolytica are dominant anaerobes in lower respiratory tract infection in horses.

\section{Biosensors}

Biosensor is an advanced technique for the detection of either the antigen or antibodies. This assay involves the use of a receptor (mostly an antibody), a disease specific antibody and a transducer that converts a biological interaction into a measurable signal (Cruz et al., 2002). These biosensors are frequently coupled to sophisticated instrumentation to produce highly-specific analytical tools, most of which are still in use only for the research and development purpose due to the high cost of instrumentation, high cost of individual sample analysis, and the need for highly trained persons to oversee the testing. Fibre optic biosensors have the potential to do multianalyte analyses in an automated format. Portable fibre optic biosensors, has been reported to detect four different analytes in one coupon (King et al., 2000). Biosenors can be used as self-contained field devices for the detection of foreign animal disease agents. West nile virus was detected using biosensors and microfluidic systems, a linear, 15 amino acid fragment of domain III of WNV was successfully used as an antigen on an amperometric immunosensor (Ionescu et al., 2007). Neng et al. (2010) reported that, a surface enhanced Raman scattering immunoassay was shown to be highly sensitive for the 
detection of anti-WNV immunoglobulin. Hu et al. (2004) developed a genetically biotinylated single chain fragment variable antibody (scFv) against Venezuelan equine encephalitis virus (VEE). Patrick et al. (2014) studied the evolution of equine influenza and the origin of canine influenza with the help of biosensor.

\section{Nanotechnology}

The systems or devices which are related to the features of nanometre scale are broadly defined as nanotechnology. This scale of technology as it applies to diagnostics would include the detection of molecular interactions. The tiny dimensions of this technology led a basement to the use of nanoarrays and nanochips as test platforms (Jain, 2003). The potential use of this technology is to analyse a sample for an array of infectious agents on a single chip. Many research groups are considering the use of chip assays that detect several agroerrorism agents in each sample. Small, portable platforms are being designed to allow pen-side testing of animals for diseases of concern.

The use of nanoparticles to label antibodies is another facet of nanotechnology. These labelled antibodies can be used in various assays to identify specific pathogens, structures or molecules. The use of gold nanoparticles, nanobarcodes, quantum dots and nanoparticle probes are the examples of nanotechnology (Yguerabide \& Yguerabide, 2001). Nanopores, nanosensors, resonance light scattering and cantilever arraysare some of the additional nanotechnologies and it is anticipated that many of the specific nanotechnologies will eventually be applied to the diagnosis of endemic veterinary diseases in the future. Klier et al. (2012) reported about an aerosol formulation of biodegradable, biocompatible and nontoxic gelatine nanoparticle-bound CpG-ODN2216, to treat equine recurrent airway obstruction in a clinical study.

\section{Proteomics}

Proteomics is the new emerging field to isolate and characterize the protein produced by various etiological agents. Different bacterial, viral as well as parasitic proteins can be targeted with the help of this technology. Hence, proteomics has potential applications in veterinary diagnostics. The usual approach of proteomic involves separation of the proteins with the help of two dimension gel electrophoresis and staining them with appropriate protein marker. The protein 'pattern' is different in different species; hence it can be recognized as a fingerprint. It is then analyzed by performing image analysis (Krah \& Jungblut, 2004). Proteins that are up- or downregulated due to disease are compared and find by using proteome maps. A protein of interest can be cut and taken out from the gel and purified. This purified protein can be further fully characterized using peptide-mass fingerprinting and/ or mass spectrometry methods. Veterinary diagnostics may make use of proteomics to identify or look for known disease markers or patterns with biochip technology and instrumentation that combines mass spectrometry with other separation chromatography or molecular techniques in the future. These instrumentations are designed to specifically select, separate by molecular mass, and identify the complex mixture of proteins in a sample, which can be compared to known samples for diagnostic purposes.

In equine medicine, proteomics is been used in the diagnosis of different metabolic as well as orthopedic diseases which show some of the alteration in the expression levels of marker proteins (Amaya, 2014). In the proteomic marker analysis conducted in biopsy samples of horse muscles, it was found that three significantly increased proteins: alpha actin, tropomyosin alpha chain and creatine kinase $\mathrm{M}$ chain (CKM). CKM was represented by multiple spots probably due to posttranslational modification, one of which appeared to be unique for tying-up suggesting that altered energy distribution within muscle cells is part of the disease etiology (Freek et al., 2010a). In another study they have identified, 20 differential spots representing 16 different proteins. Evaluation of those proteins complies with adaptation of the skeletal muscle after normal training involving structural changes towards a higher oxidative capacity, an increased capacity to take up long-chain fatty acids, and to store energy in the form of glycogen.

Intensified training leads to additional changed spots. Alpha-1antitrypsin was found increased after intensified training but not after normal training. This protein may thus be considered as a marker for overtraining in horses and also linked to overtraining in human athletes (Freek et al., 2010b). In an another study, which was conducted on the proteomics, study of cerebrospinal fluid, a total of 320 proteins were confidently identified across six healthy horses, and these proteins were further characterized by gene ontology terms mapped in UniProt, and normalized spectral abundance factors were calculated as a measure of relative abundance and these results provide an optimized protocol for analysis of equine CSF and laid the basement for future studies involving the CSF study of equines in the context of pathogenic disease states (Carolyn et al., 2014). The analysis of osteoarthritis and osteochondrosis conducted by Elisabetta et al. (2012) has identified some putative protein markers which can be further tried for the definitive early diagnosis of osteoarthritis in the horses. A highly sensitive proteomic comparison together with insightful data mining enabled us to identify proteins and pathways involved in early OA which could aid the development of early OA diagnostic markers and therapeutics (Peffers et al., 2012). In case of a very unpredictable disease of equines, laminitis identification and measurement of novel protein biomarkers present in blood that predict the onset and resolution of laminitis would both aid clinical management of at-risk equine patients and shed light on underlying mechanisms with the intent of developing novel preventive strategies and therapeutic approaches (Joseph et al., 2008).

\section{Conclusion}

A profound change has been occurred in recent years in veterinary diagnostics with the introduction of new biotechnological assays which completely changed the 
scenario of time-tested, traditional diagnostic techniques of veterinary disease diagnosis. These new biotechnological methods, includes the production of more specific antigens by the use of recombination, expression vectors and synthetic peptides. When coupled with the use of monoclonal antibodies, the sensitivity and specificity of a number of traditional diagnostic assays have been significantly improved. Various forms of PCR have become a routine diagnostic tool in veterinary laboratories for rapid screening of large number of samples during disease outbreaks to develop prevention and control measures and also to make specific typing determinations for research purpose.

Other technologies are likely to be widely adopted in the future as they demonstrate the ability to improve the diagnostic capabilities while reducing the time and, perhaps cost associated with more conventional technologies. Proteomics has the potential to look at the broader picture of protein expression for a pathogen of interest or by infected animals and it may lead to a special niche of veterinary diagnostics. Nanotechnologies hold the promise of screening numerous pathogens in a single assay, while not yet implemented in veterinary laboratories. Nanotechnology has become the choice for mobile and pen-side testing of animal diseases due to its small size and easy handling. Biotechnology and its applications hold the great promise for improving the speed and accuracy of diagnostic tests for veterinary pathogens. Much developmental work will be required to realise the potential with well-characterised, validated assay systems that provide improved diagnostic capabilities to safeguard animal health.

Traditionally, pathogens were detected by microscopic and other conventional methods of various biological samples. Later on several molecular and serological assays have been employed for diagnostic purpose. These assays are shown highly effective and sensitive results for the detection of parasites regardless of the type of infection and sample. Among the various available techniques, some are used for treatment monitoring along with the diagnosis of parasites. Thus they became a useful tool in the clinical decision making process. The molecular and serological methods are also useful in vast epidemiological studies, because they are also involved in the geographical distribution study of parasites, genetic diversity of populations, susceptibility of infections and mutations in parasites. Detailed knowledge about the genetic characteristics, morphology and behaviour of parasitic disease in the affected population is provided by the molecular tools. Although, the cost of molecular diagnosis is higher than the conventional methods, they are highly used in veterinary clinical diagnosis, epidemiological studies and treatment monitoring of animals. The suitable molecular tests showing rapid, sensitive, accurate and reliable result and which can detect all or most targeted pathogens in a multiplex amplification system should be developed. Moreover, for faster surveillance strategies and monitoring of parasitic epidemiology automated technology should be developed to process the large number of serum samples for antibody detection. Recently, advanced software tools and the computing power for bioinformatics analysis of parasitic large genome size data is a need of modern molecular diagnosis. The major challenge regarding development of new technologies is to optimize and evaluate the tools for control and eradication programs of parasitic diseases. So it will help in the development of newer technologies to a level of analytical sensitivity which will be appropriate for testing of clinical samples directly without previous processing.

\section{Conflict of interest}

Authors would hereby like to declare that there is no conflict of interests that could possibly arise.

\section{References}

Abdelgawad A, Hermes R, Damiani A, Lamglait B, Czirják GA, East M (2015) Comprehensive Serology Based on a Peptide ELISA to Assess the Prevalence of Closely Related Equine Herpesviruses in Zoo and Wild Animals. PLoS ONE 10 : e0138370. DOI:10.1371/journal.pone.0138370.

Alhassan A, Thekisoea OM, Yokoyamaa N, Inouea N, Motloangb MY, Mbati PA (2007) Development of loopmediated isothermal amplification (LAMP) method for diagnosis of equine piroplasmosis. Veterinary Parasitology 143:155-60. DOI: 10.1016/j.vetpar.2006.08.014

Alvarez I, Gutierrez G, Barrandeguy M, Trono K (2010) Immunochromatographic lateral flow test for detection of antibodies to Equine infectious anemia virus. Journal of Virological Methods 167 :152-157. DOI: 10.1016/j.jviromet.2010.03.026

Amavisit GF, Browning D, Lightfoot S, Church GA, Anderson KG, Whithear PF, Markham P (2001) Rapid PCR detection of Salmonella in horse faecal samples. Veterinary Microbiology 79: 63-74.

Amaya M (2014) Proteomic strategies for the discovery of novel diagnostic and therapeutic targets for infectious diseases. Pathogen Disease 71:177-188. DOI: 10.1111/2049632X.12150

Balasuriya UB, Leutenegger CM, Topol JB (2002) Detection of equine arteritis virus by real-time TaqMan reverse transcription-PCR assay. Journal of Virological Methods 101:21-28.

Bannai H, Manabu N, Koji T, Takashi Y, Ken M, Takashi K (2016) Improvement of an enzyme-linked immunosorbent assay for by using a synthetic-peptide 24-mer repeat sequence of glycoprotein $\mathrm{G}$ as an antigen. Journal of Veterinary Medical Science $78: 309-311$.

Bannai H, Nemoto M, Tsujimura K, Yamanaka T, Kondo T, Matsumura T (2013) Improving a Complement-fixation Test 
for Equine Herpesvirus Type-1 by Pretreating Sera with Potassium Periodate to Reduce Non-specific Hemolysis. Journal of Equine veterinary Science 24 :71-74.

Battsetseg B, Xuan X, Ikadai H, Bautista JL, Byambaa B, Boldbaatar D, Battur B, Battsetseg G, Batsukh Z, Igarashi I, Nagasawa H, Mikami T, Fujisaki K (2001) Detection of Babesia caballi and Babesia equi in dermacentornuttalli adult ticks. International Journal of Parasitology 31:384-386.

Beltrao MROC, Alencar CAS, Leite AS, Freitas LT, Gonzalez JC, Santana VLA, MansoFilho HC (2015) Comparison of Two Protocols of Agar Gel Immunodiffusion (AGID) Used to Diagnose of Equine Infectious Anemia (EIA). Open Journal of Veterinary Medicine 5: 169-174. doi: 10.4236/ojvm.2015.57023.

Booth MG, Hood J, Brooks TJ, Hart A (2010) Health protection Scotland anthrax clinical network. Anthrax infection in drug users. The Lancet 375: 1345-1346. DOI: http://dx.doi.org/10.1016/S0140-6736(10)60573-9

Borchers K, Wiik H, Frolich K, Ludwig H, East ML (2005) Antibodies against equine herpesviruses and equine arteritis virus in Burchell's zebras (Equus burchelli) from the Serengeti ecosystem. Journal of Wildlife Diseases 41:80-6. DOI: 10.7589/0090-3558-41.1.80

Brendan SC, Michael J (1993) Epitopes of glycoprotein g of equine herpesviruses 4 and 1 located near the $\mathrm{c}$ termini elicit type-specific antibody responses in the natural host. Journal of Virology 67 : 6332-6338.

Bretagne S, Costa JM (2006) Towards a nucleic acid based diagnosis in clinical parasitology and mycology. Clinica Chimica Acta 363 : 221-228.

Brosnahan MM, Miller DC, Adams M, Antczak DF. (2012) IL-22 is expressed by the invasive trophoblast of the equine (Equus caballus) chorionic girdle. Journal of Immunology 188:4181-4187.

Bumgarner R (2013) Overview of DNA microarrays: types, applications, and their future. Current Protocols in Molecular Biology Chapter 22:22.1.

Burnouf T, Griffiths E, Padilla A, Seddik S, Stephanoe MA, Gutierrez JM (2004) Assessment of the viral safety of antivenoms fractionated from equine plasma. Biologicals 32 : 115-128. DOI: 10.1016/j.biologicals.2004.07.001

Burton AB, Perkins GA, Parker J, Rosenthal R, Baumgart M, Simpson KW (2007) The gastric mucosa of horses harbours an abundant and diverse bacterial flora. Proceedings of American College of Veterinary Internal Medicine, Annual meeting, Seattle, WA.
Carolyn J, Broccardo, Gisela SH, Lutz G, Paul L, Jessica EP (2014) Proteomic Characterization of Equine Cerebrospinal Fluid. Journal of Equine Veterinary Science 34 : 451-458. http://dx.doi.org/10.1016/j.jevs.2013.07.013

Carvalho R, Passos LMF, Martins AS (2000). Development of a Differential Multiplex PCR Assay for Equine Herpesvirus 1 and 4 as a Diagnostic Tool. Zoonoses and Public Health 47 : 351-359.

Chhabra S, Khurana SK, Kapoor PK, Singha H, Singh Y, Khirbat R (2015) Characterization of Rhodococcus equi isolates from foals with respiratory problems using a multiplex PCR for the vap genes. Advances in Animal and Veterinary Sciences $\quad 3 \quad$ : $28-32$. http://dx.doi.org/10.14737/journal.aavs/2015/3.1s.28.32

Chung KM, Diamond MS (2008) Defining the levels of secreted non-structural protein NS1 after West Nile virus infection in cell culture and mice. Journal of Medical Virology 80:547-556.

Contreras M, Morales A, Garcia-Amado MA, De Vera M, Bermudez V, Gueneau P (2007) Detection of Helicobacter-like DNA in the gastric mucosa of Thoroughbred horses. Letters in Applied Microbiology 45: 553-557. DOI: 10.1111/j.1472765X.2007.02227.x

Cook RF, Cook SJ, Li F, Montelaro RC, Issel CJ (2002) Development of a multiplex real-time reverse transcriptasepolymerase chain reaction for equine infectious anemia virus (EIAV). Journal of Virological Methods 105: 171-179.

Cruz H, Rosa C, Oliva A (2002) Immunosensors for diagnostic applications. Parasitology Research 88: 4-7. DOI: 10.1007/s00436-001-0559-2

Cushwa WT, Medrano JF (1996) Applications of the random amplified polymorphic DNA (RAPD) assay for genetic analysis of livestock species. Animal Biotechnology 7 : 11-31. http://dx.doi.org/10.1080/10495399609525845

Diallo IS, Glen H, Lucia W, Barry JR, Bruce GC (2006) Detection of equine herpesvirus type 1 using a real-time polymerase chain reaction. Journal of Virological Methods 131: 92-98. DOI: 10.1016/j.jviromet.2005.07.010

Diallo IS, Glen H, Lucia W, Mark AK, Barry JR, Bruce GC (2007) Multiplex real-time PCR for the detection and differentiation of equid herpesvirus 1 (EHV-1) and equid herpesvirus 4 (EHV-4). Veterinary Microbiology 123: 93-103.

Dicken M, Munday JS, Archer RM, Mayhew IG, Pandey SK. (2010) Cutaneous fungal granulomas due to Alternaria spp. infection in a horse in New Zealand. New Zealand Veterinary Journal $58: 319-320$. 
Doan R, Cohen ND, Sawyer J, Ghaffari N, Johnson CD, Scott VD (2012) Whole Genome sequencing and genetic variant analysis of a quarter Horse mare. BMC Genomics 13: 78. DOI: $10.1186 / 1471-2164-13-78$.

Druce, Mike C, Doris C, Kirsty M, David T, Renata K, Bill M, Wendy LS, Marie G, Chris B, (2002) Utility of a Multiplex PCR Assay for Detecting Herpesvirus DNA in Clinical Samples. Journal of Clinical Microbiology 1728-1732.

Duarte PC, Daft BM, Conrad PA, Packham AE, Gardner IA (2003) Comparison of a serum indirect fluorescent antibody test with two Western blot tests for the diagnosis of equine protozoal myeloencephalitis. Journal of Veterinary Diagnostic Investigation $15: 8-13$.

Duarte PC, Ebel ED, Traub-Dargatz J, Wilson WD, Conrad PA, Gardner IA (2006) Indirect fluorescent antibody testing of cerebrospinal fluid for diagnosis of equine protozoal myeloencephalitis. American Journal of Veterinary Reserach 67 : 869-876. DOI: 10.2460/ajvr.67.5.869

Eischeid AC (2011) SYTO dyes and EvaGreen outperform SYBR Green in real-time PCR. BMC Research Notes 4:263. DOI: $10.1186 / 1756-0500-4-263$. DOI: 10.1186/1756-0500-4263

Elisabetta C, Marco P, Micaela T, Fausto S, Chiara D, Giovanni R, Luca A, Franco M, Alberto G, Andrea B, Francesca B, Andrea S (2012) Gambling on putative biomarkers of osteoarthritis and osteochondrosis by equine synovial fluid proteomics. Journal of Proteomics Special Issue: Farm Animal Proteomics 75 : 4478-4493. DOI: 10.1016/j.jprot.2012.02.008

Erol E, Jackson CB, Steinman M, Meares K, Donahoe J, Kelly N, Locke S, Smith JL, Carter CN (2015) A diagnostic evaluation of real-time PCR, fluorescent antibody and microscopic agglutination tests in cases of equine leptospiral abortion. Equine Veterinary Journal 47 :171-174. DOI: 10.1111/evj.12281

Faber NA, Melissa C, Rance B, Lefebvre, Nedim C, Buyukmihci, John E, Madigan, Neil HW (2000) Detection of Leptospira spp. in the Aqueous Humor of Horses with Naturally Acquired Recurrent Uveitis. Journal of Clinical Microbiology 38: 2731-2733.

Ferris NP, Clavijo A, Yang M, Velazquez-Salinas L, Nordengrahn A, Hutchings GH, Kristersson T, Merza M (2012) Development and laboratory evaluation of two lateral flow devices for the detection of vesicular stomatitis virus in clinical samples. Journal of Virological Methods 180 : 96-100. DOI: $10.1016 /$ j.jviromet.2011.12.010

Finno CJ, Spier SJ, Valberg SJ (2009) Equine diseases caused by known genetic mutations. Veterinary Journal $179: 336$ 347. http://dx.doi.org/10.1016/j.tvj1.2008.03.016
Finno CJ, Bannasch DL (2014) Applied equine genetics Equine. Veterinary Journal 46 : 538-544. DOI: 10.1111/evj.12294

Foley JE, Sharon JS, Judy M, Niki BS, Drazenovich MS, Christian ML (2004) Molecular epidemiologic features of Corynebacterium pseudotuberculosis isolated from horses. American Journal of Veterinary Research 65: 1734-1737.

Freek G, Bouwmana, Mireille ME, van Ginnekenb, Jean-Paul $\mathrm{N}$, Erik R, Ellen de Graaf-R, Inge DW, Johannes H, van der K, Edwin CM, Eric van B (2010a) Differential expression of equine muscle biopsy proteins during normal training and intensified training in young standard bred horses using proteomics technology. Comparative Biochemistry and Physiology Part D: Genomics and Proteomics 5 : 55-64. DOI: 10.1016/j.cbd.2009.11.001

Freek G, Bouwmana, Mireille ME, van Ginnekenc, Johannes H, van der Kolkc, Eric van B, Edwin CM, Mariman (2010b) Novel markers for tying-up in horses by proteomics analysis of equine muscle biopsies. Comparative Biochemistry and Physiology Part D: Genomics and Proteomics 178-183. DOI: 10.1016/j.cbd.2010.03.009

Gardner SN, McLoughlin K, Be NA, Allen J, Weaver SC, Forrester N (2016) Characterization of Genetic Variability of Venezuelan Equine Encephalitis Viruses. PLoS ONE 11 : e0152604. DOI:10.1371/journal.pone.0152604. DOI: 10.1371/journal.pone.0152604

Gasser RB (2006) Molecular tools- advances, opportunities and prospects. Veterinary Parasitology 136 : 69-89. DOI: 10.1016/j.vetpar.2005.12.002

Gilissen (2014) Genome sequencing identifies major causes of severe intellectual disability. Nature 511 : 344 . DOI: 10.1016/j.vetpar.2005.12.002

Goodman LB, Loregian A, Perkins GA, Nugent J, Buckles EL, Mercorelli B, Kydd JH, Palu G, Smith KC, Osterrieder N, Davis-Poynter N (2007) A point mutation in a herpesvirus polymerase determines neuropathogenicity. PLoS Pathogen 3: e160. DOI: 10.1371/journal.ppat.0030160

Goto M, Shimada K, Sato A, Takahashi E, Fukasawa T, Takahashi T, Ohka S, Taniguchi T, Honda E, Nomoto A, Ogura A, Kirikae T, Hanaki K (2010) Rapid detection of Pseudomonas aeruginosa in mouse feces by colorimetric loopmediated isothermal amplification. Journal of Microbiological Methods 81:247-52. DOI: 10.1016/j.mimet.2010.03.008

Green S, Laue B, Fossdal CG, A Hara SW, Cottr JE (2009) Infection of horse chestnut (Aesculus hippocastanum) by Pseudomonas syringe pv. aesculi and its detection by quantitative real-time PCR. Plant Pathology 58 : 731-744. DOI: $10.1111 / j .1365-3059.2009 .02065 . x$ 
Hartley CA, Wilks CR, Studdert MJ, Gilkerson JR (2005) Comparison of antibody detection assays for the diagnosis of equine herpesvirus 1 and 4 infections in horses. American Journal of Veterinary Research 66 : 921-928.

Hill J, Beriwal S, Chandra I, Paul VK, Kapil A, Singh T, Wadowsky RM, Singh V, Goyal A, Jahnukainen T, Johnson JR, Tarr PI, Vats A (2008) Loop-mediated isothermal amplification assay for rapid detection of common strains of Escherichia coli. Journal of Clinical Microbiology 46: 2800-4.

Hu WG, Thompson HG, Alvi AZ, Nagata LP, Suresh MR, Fulton RE (2004) Development of immunofiltration assay by light addressable potentiometric sensor with genetically biotinylated recombinant antibody for rapid identification of Venezuelan equine encephalitis virus. Journal of Immunological Methods 289 : 27-35. DOI: 10.1016/j.jim.2004.03.007

Ijaz M, Khan MS, Khan MA, Maqbool A, Ali MM, Rehman A, Mehmood K, Saleem MH, Shabbir MZ (2012) Comparative study of culture and pcr for detection of carriers of streptococcus equi in naturally infected mules in Pakistan. Journal of Animal and Plant Sciences 22 : 256-259.

Ionescu RE, Cosnier S, Herrmann S, Marks RS (2007) Amperometric immunosensor for the detection of anti-West Nile virus IgG. Analytical Chemistry 79 : 8662-8668.

Jain K (2003) Nanodiagnostics: application of nanotechnology in molecular diagnostics. Expert Review of Molecular Diagnostics 3 : 153-161. DOI: 10.1586/14737159.3.2.153

Jain S, Wyatt D, McCaughey C, O'Neill HJ, Coyle PV (2001) Nested multiplex polymerase chain reaction for the diagnosis of cutaneous herpes simplex and herpes zoster infections and a comparison with electron microscopy. Journal of Medical Virology 63:52-56. DOI: $10.1002 / 1096-$ 9071(200101)63:1<52::AID-JMV1007>3.0.CO;2-H

Janse I, Raditijo AH, Amber CA, Hendriks, Bart JR (2013) Multiplex qPCR for reliable detection and differentiation of Burkholderia mallei and Burkholderia pseudomallei. BMC Infectious Diseases 13:86. DOI: 10.1186/1471-2334-13-86

Javed R, Taku AK, Gangil R, Sharma RK (2016) Molecular characterization of virulence genes of Streptococcus equi subsp. equi and Streptococcus equi subsp. zooepidemicus in equines. Veterinary World $9: 875-881$.

John JM, Kapoor PK, Malik PK (2010) Serodiagnosis of glanders by dot-ELISA using various antigens. Indian Journal of Animal Sciences $80: 1084-86$.

Johnson AL, Morrow JK, Sweeney RW (2013) Indirect fluorescent antibody test and surface antigen ELISAs for antemortem diagnosis of equine protozoal myeloencephalitis.
Journal of Veterinary Internal Medicine 27 :596-599. DOI: $10.1111 /$ jvim. 12061

Johnson DJ, Ostlund EN, Pedersen DD, Schmitt BJ (2001) Detection of North American West Nile virus in animal tissue by a reverse transcription-nested polymerase chain reaction assay. Emerging Infectious Disease 7:739-41. DOI: 10.3201/eid0704.010425

Johnson N, Wakeley PR, Mansfield KL, McCracken F, Haxton B, Phipps LP, Fooks AR (2010) Assessment of a novel realtime pan-flavivirus RT-polymerase chain reaction. Vector Borne Zoonotic Diseases 10:665-671. DOI: 10.1089/vbz.2009.0210

Joseph L, Mankowski, David R, Graham (2008) Potential Proteomic-Based Strategies for Understanding Laminitis: Predictions and Pathogenesis. Journal of Equine Veterinary $\begin{array}{llll}\text { Science } & 28 & : & 484-487 .\end{array}$ http://dx.doi.org/10.1016/j.jevs.2008.07.011

Khurana SK (2015) Current understanding of Rhodococcus equi infection and its zoonotic implications. Advances in Animal and Veterinary Sciences $3: 1-10$. DOI : 10.14737/journal.aavs/2015/3.1.1.10

Khurana SK, Singha H, Malik P, Gulati BR, Singh RK (2015) Molecular characterization of clinical isolates of Rhodococcus equi with PCR assay based on virulence plasmid marker. Indian Journal of Animal Sciences 85 : 1063-1066.

Kim C, Lidia BCB, Andy A, Hiroshi I, Naoaki Y, Xuenan X, Ikuo I (2008) Diagnostic real-time PCR assay for the quantitative detection of Theileria equi from equine blood samples. Veterinary Parasitology 151: 158-163. DOI: 10.1016/j.vetpar.2007.10.023

King K, Vanniere J, Leblanc J, Bullock K, Anderson G (2000) Automated fiber optic biosensor for multiplexed immunoassays. Environment Science and Technology 34: 2845-2850. DOI: 10.1021/es9913535

Kinoshita Y, Niwa H, Katayama Y (2015) Use of loopmediated isothermal amplification to detect six groups of pathogens causing secondary lower respiratory bacterial infection in horses. Microbiology and Immunology 59, 365370. DOI: $10.1111 / 1348-0421.12257$

Kinoshita Y, Niwa H, Katayama Y, Hariu K (2014) Dominant obligate anaerobes revealed in lower respiratory tract infection in horses by $16 \mathrm{~S}$ rRNA gene sequencing. Journal of Veterinary Medicine and Science 76:587-591.

Klier J, Fuchs S, May A, Schillinger U, Plank C, Winter G, Coester C, Gehlen H (2012) A nebulized gelatin nanoparticlebased $\mathrm{CpG}$ formulation is effective in immunotherapy of allergic horses. Pharmaceutical Research 29 :1650-7. DOI: 10.1007/s11095-012-0686-8 
Kooijman LJ, Mapes SM, Pusterla N (2016) Development of an equine coronavirus-specific enzyme-linked immunosorbent assay to determine serologic responses in naturally infected horses. Journal of Veterinary Diagnostic Investigation 28 : 414-8. DOI: 10.1177/1040638716649643

Krah A, Jungblut P (2004) Immunoproteonomics. In Decker J, Reischl U (Eds.) Molecular diagnosis of infectious diseases. Humana Press Inc Totowa 19-32.

Kriegshauser G, Cullinane A, Kuechler E (2008) Denatured virion protein 1 of equine rhinitis $\mathrm{B}$ virus 1 contains authentic B-cell epitopes recognised in an enzymelinked immunosorbent assay-short communication. Acta Veterinaria Hungarica 56:265-270. DOI: 10.1556/AVet.56.2008.2.14

Kriegshauser G, Kuechler E, Skern T (2009) Aggregationassociated loss of antigenicity observed for denatured virion protein 1 of Equine rhinitis A virus in an enzyme-linked immunosorbent assay. Virus Research 143:130-133. DOI: 10.1016/j.virusres.2009.03.003

Lambert AJ, Martin DA, Lanciotti RS (2003) Detection of North American and western equine encephalitis viruses by nucleic acid amplification assays. Journal of Clinical Microbiology 41: 379-385.

Lanciotti RS, Kerst AJ (2001) Nucleic acid sequence-based amplification assays for rapid detection of West Nile and St. Louis encephalitis viruses. Journal of Clinical Microbiology 39:4506-4513.

Lang A, de Vries M, Feineis S, Muller E, Osterrieder N, Damiani AM (2013) Development of a peptide ELISA for discrimination between serological responses to equine herpesvirus type 1 and 4. Journal of virological methods 193 : 667-673. DOI: 10.1016/j.jviromet.2013.07.044

Larrasa J, Garcia A, Ambrose NC, Alonso JM, Parra A, de Mendoza MH, Salazar J, Rey J, de Mendoza JH (2002) A simple random amplified polymorphic DNA Genotyping method for field isolates of Dermatophilus congolensis. Journal of Veterinary Medicine B, Infectious Diseases and Veterinary Public Health 49 :135-41.

Larrasa J, Garcia-Sanchez A, Ambrose NC, Parra A, Alonso JM, Rey JM, Hermoso-de-Mendoza M, Hermoso-de-Mendoza J (2004) Evaluation of randomly amplified polymorphic DNA and pulsed field gel electrophoresis techniques for molecular typing of Dermatophilus congolensis. FEMS Microbiology Letters 240 : 87-97. DOI: 10.1016/j.femsle.2004.09.016

Lavoie JP, Drolet R, Parsons D, Leguillette R, Sauvageau R, Shapiro J, Houle L, Halle G, Gebhart CJ (2000) Equine proliferative enteropathy: a cause of weight loss, colic, diarrhoea and hypoproteinaemia in foals on three breeding farms in Canada. Equine veterinary Journal 32 : 418-425.
Lee SH, Kim KT, Yun SH, Choi E, Lee GH, Park YS, Cho KH, Yi S, Kwon OD, Kim TH, Kwak D (2015) Serological and molecular detection of Anaplasma phagocytophilum in horses reared in Korea. Veterinarni Medicina 60 : 533-538. doi: 10.17221/8491-VETMED

Leeb T, Vogl C, Zhu B, de Jong PJ, Binns MM, Chowdhary BP, Scharfe M, Jarek M, Nordsiek G, Schrader F, Blocker H (2006) A human-horse comparative map based on equine BAC end sequences. Genomics 87 : 772-6. DOI: 10.1016/j.ygeno.2006.03.002

Letek M, Ocampo-Sosa AA, Sanders M, Fogarty U, Buckley T, Leadon DP, Gonzalez P, Scortti M, Meijer WG, Parkhill J, Bentley S, Vazquez-Boland JA (2008) Evolution of the Rhodococcus equi vap pathogenicity island seen through comparison of host-associated vapA and vapB virulence plasmids. Journal of Bacteriology 190: 5797-5805. doi: 10.1128/JB.00468-08

Linssen B, Kinney RM, Aguilar P, Russel KL, Watts DM, Kaaden OR, Pfeffer M (2000) Development of reverse transcription-PCR assays specific for detection of equine encephalitis viruses. Journal of Clinical Microbiology 38: $1527-1535$.

M'ghirbi Y, Hela Y, Abderazek G, Ali B (2012) Anaplasma phagocytophilum in horses and ticks in Tunisia. Parasites and Vectors 5:180.

Ma G, Azab W, Osterrieder N (2013) Equine herpesviruses type 1 (EHV-1) and 4 (EHV-4) masters of coevolution and a constant threat to equids and beyond. Veterinary Microbiology 167 : 123-34. DOI: 10.1016/j.vetmic.2013.06.018

Macdonald J, Tonry J, Hall RA, Williams B, Palacios G, Ashok MS, Jabado O, Clark D, Tesh RB, Briese T, Lipkin WI (2005) NS1 protein secretion during the acute phase of West Nile virus infection. Journal of Virology 79:13924-13933. DOI: 10.1128/JVI.79.22.13924-13933.2005

McCue ME, Valberg SJ, Miller MB, Wade C, DiMauro S, Akman HO, Mickelson JR (2008) Glycogen synthase (GYS1) mutation causes a novel skeletal muscle glycogenosis. Genomics 91 : 458-466. DOI: 10.1016/j.ygeno.2008.01.011

McFadden AM, Hanlon D, McKenzie RK, Gibson I, Bueno IM, Pulford DJ, Orr D, Dunowska M, Stanislawek WL, Spence RP, McDonald WL,Munro G, Mayhew IG (2016) The first reported outbreak of equine herpesvirus myeloencephalopathy in New Zealand. New Zealand Veterinary Journal 64 :125-34. DOI: $10.1080 / 00480169.2015 .1096853$

Mienaltowski MJ, Huang L, Frisbie DD, McIlwraith CW, Stromberg AJ, Bathke AC, Macleod JN (2009) Transcriptional profiling differences for particular cartilage and repair tissue in 
equine joint surface lesions. BMC Medicine Genomics 2:60. DOI: $10.1186 / 1755-8794-2-60$

Monego F, Maboni F, Krewer C, Vargas A, Costa M, Loreto E (2009) Molecular characterization of Rhodococcus equi from horse-breeding farms by means of multiplex PCR for the vap gene family. Current Microbiology 58 : 399-403. DOI: 10.1007/s00284-009-9370-6

Morris C, Field H (1988) Application of cloned fragments of equine herpesvirus type-1 DNA for detection of virus-specific DNA in equine tissues. Equine Veterinary Journal $20: 335$ 340.

Nagamine K, Hase T, Notomi T (2002) Accelerated reaction by loop-mediated isothermal amplification using loop primers. Molecular and Cellular Probes 16:223-9.

Ndao M (2009) Diagnosis of parasitic diseases: old and new approaches. Interdisciplinary Perspection of Infectious Diseases 2009:1-15. http://dx.doi.org/10.1155/2009/278246

Nemoto M, Imagawa H, Tsujimura K, Yamanaka T, Kondo T, Matsumura T (2010) Detection of equine rotavirus by reverse transcription loop-mediated isothermal amplification (RTLAMP). Journal of Veterinary Medical Science 72 :823-6.

Nemoto M, Takashi Y, Hiroshi B, Koji T, Takashi K, Tomiomatsumura (2011) Development and evaluation of a reverse transcription loop-mediated isothermal amplification assay for H3N8 equine influenza virus. Journal of virological methods 178: 239-242. DOI: 10.1016/j.jviromet.2011.07.015

Nemoto M, Takashi Y, Hiroshi B, Koji T, Takashi K, Tomiomatsumura (2012) Development and evaluation of a reverse transcription loop-mediated isothermal amplification assay for H7N7 equine influenza virus. Journal of veterinary medical science.74: 929-931.

Neng J, Harpster MH, Zhang H, Mecham JO, Wilson WC, Johnson PA (2010) A versatile SERS-based immunoassay for immunoglobulin detection using antigen-coated gold nanoparticles and malachite green-conjugated protein A/G. Biosensors and Bioelectronics $26: 1009-1015$. DOI: 10.1016/j.bios.2010.08.015

Nielsen MK, David S, Peterson, Jesper M, Stig M, Thamsborg, Susanne N, Olsen, Ray MK (2008) Detection and semiquantification of Strongylus vulgaris DNA in equine faeces by real-time quantitative PCR. International Journal for Parasitology 38: 443-453. http://dx.doi.org/10.1016/j.ijpara.2007.07.014

Nogueira ML, Amorim JB, Oliveira JG, Bonjardim CA, Ferreira PC, Kroon EG (2000) Comparison of virus isolation and various polymerase chain reaction methods in the diagnosis of mucocutaneous herpesvirus infection. Acta Virologica 44:61-65.
Nones K, Waddell N, Wayte N, Patch AM, Bailey P, Newell F, Holmes O, Fink JL, Quinn MC, Tang YH, Lampe G, Quek K, Loffler KA, Manning S, Idrisoglu S, Miller D, Xu Q, Waddell N, Wilson PJ, Bruxner TJ, Christ AN, Harliwong I, Nourse C, Nourbakhsh E, Anderson M, Kazakoff S, Leonard C, Wood S, Simpson PT, Reid LE, Krause L, Hussey DJ, Watson DI, Lord RV, Nancarrow D, Phillips WA, Gotley D, Smithers BM, Whiteman DC, Hayward NK, Campbell PJ, Pearson JV, Grimmond SM, Barbour AP (2014) Genomic catastrophes frequently arise in esophageal adenocarcinoma and drive tumorigenesis. Nature Communications 5: 5224. DOI:10.1038/ncomms6224

Noschka E, Vandenplas ML, Hurley DJ, Moore JN (2009) Temporal aspects of laminar gene expression during the developmental stages of equine laminitis. Veterinary Immunology and Immunopathology 129:242-253. DOI: 10.1016/j.vetimm.2008.11.002

Notomi T, Okayama H, Masubuchi H, Yonekawa T, Watanabe $\mathrm{K}$, Amino N, Hase T (2000) Loop-mediated isothermal amplification of DNA. Nucleic Acids Research 28: e63.

Nugent J, Birch-Machin I, Smith KC, Mumford JA, Swann Z, Newton JR, Bowden RJ, Allen GP, Davis-Poynter N (2006) Analysis of equine herpesvirus type 1 strain variation reveals a point mutation of the DNA polymerase strongly associated with neuropathogenic versus non-neuropathogenic disease outbreaks. Journal of Virology 80: 4047-4060.

Ocampo-Sosa AA, Lewis DA, Navas J, Quigley F, Callejo R, Scortti M, Leadon DP, Fogarty U, Vazquez-Boland JA (2007) Molecular epidemiology of Rhodococcus equi based on traA, vapA, and vapB virulence plasmid markers. Journal of Infectious Diseases 196 : 763-769. DOI: 10.1086/519688

OIE (2016) OIE Terrestrial Manual 2016.

Oldfield C, Bonella H, Renwick L, Dodson HI, Alderson G, Goodfellow M (2004) Rapid determination of vapA/vapB genotype in Rhodococcus equi using a differential polymerase chain reaction method. Antonie Van Leeuwenhoek 85 : 317 326. DOI: 10.1023/B:ANTO.0000020383.66622.4d

Pal M, Rahman MT (2015) Rhodococcusequi: An emerging zoonotic pathogen. Annals of Veterinary and Animal Science $2: 3-10$.

Palaniappan RU, Chang YF, Chang CF, Pan MJ, Yang CW, Harpending P, McDonough SP, Dubovi E, Divers T, Qu J, Roe $B$ (2005) Evaluation of lig-based conventional and real time PCR for the detection of pathogenic leptospires. Molecular and Cellular Probes 19: 111-117. DOI: 10.1016/j.mcp.2004.10.002

Papin JF, Vahrson W, Dittmer DP (2004) SYBR green-based real-time quantitative PCR assay for detection of West Nile Virus circumvents false-negative results due to strain variability. Journal of Clinical Microbiology 42:1511-1518. 
Parida M, Sannarangaiah S, Dash PK, Rao PVL, Morita K (2008) Loop Mediated Isothermal Amplification (LAMP): A new generation of innovative gene amplification technique; perาspectives in clinical diagnosis of infectious diseases. Reviews in Medical Virology 18:407-21. DOI: 10.1002/rmv.593

Patrick J, Collinsa B, Sebastien G, Vachieria, Lesley F, Haireb, Roksana W, Ogrodowiczb, Stephen R, Martinc, Philip A, Walkerb, Xiaoli X, Steven J, Gamblinb J, Skehela J (2014) Recent evolution of equine influenza and the origin of canine influenza. PNAS 111 : 11175-11180. DOI: 10.1073/pnas.1406606111

Paxson J (2008) Evaluating Polymerase Chain Reaction-Based Tests for Infectious Pathogens. Equine compendium 308-320.

Peffers MJ, Beynon RJ, Thornton D, Clegg PD (2012) Proteomic characterisation and quantification of an in-vitro early equine osteoarthritis model. Osteoarthritis and Cartilage 20 : 261-262. DOI: http://dx.doi.org/10.1016/j.joca.2012.02.439

Perkins GA, den Bakker HC, Burton AJ (2012) Equine stomachs harbor an abundant and diverse mucosal microbiota. Applied Environmental Microbiology 78: 2522-2532. DOI: 10.1128/AEM.06252-11

Priestnall SL, Schoniger S, Ivens PA, Eickmann M, Brachthauser L, Kehr K, Tupper C, Piercy RJ, Menzies-Gow NJ, Herden C (2011) Borna Disease virus infection of a horse in Great Britain. Veterinary Record 168: 380b. doi:10.1136/vr.c6405

Pusterla N, Barbara A, Byrne, Emir H, Samantha M, Spencer S, Jang K, Gary M (2010) Use of quantitative real-time PCR for the detection of Salmonella spp. in fecal samples from horses at a veterinary teaching hospital. The Veterinary Journal 186: 252-255. DOI: http://dx.doi.org/10.1016/j.tvj1.2009.08.022

Pusterla N, Madigan JE, Leutenegger CM (2006) Real-Time Polymerase Chain Reaction: A Novel Molecular Diagnostic Tool for Equine Infectious Diseases. Journal of Veterinary Internal Medicine 20: 3-12.

Pusterla N, Pesavento PA, Leutenegger CM, Hay J, Lowenstine LJ, Durando MM, Magdesian KG (2002) Disseminated pulmonary adiaspiromycosis caused by Emmonsiacrescens in a horse. Equine Veterinary Journal 34 : 749-752.

Pusterla N, Samantha M, Daniel R, Connie G (2008) Detection of Lawsonia intracellularis by Real-time PCR in the Feces of Free-living Animals from Equine Farms with Documented Occurrence of Equine Proliferative Enteropathy. Journal of Wildlife Diseases 44 : 992-998. DOI: 10.7589/0090-355844.4 .992
Pusterla N, Wilson WD, Mapes S, Leutenegger CM (2007) Diagnostic evaluation of real-time PCR in the detection of Rhodococcus equi in faeces and nasopharyngeal swabs from foals with pneumonia.Veterinary Records $161: 272-275$. DOI: $10.1136 /$ vr.161.8.272

Quereda A, Corrall I, Laguna F, Valencia ME, Tenorio A. Echeverria JE, Navas E, Martin-Davila P, Moreno A, Moreno V, Gonzalez-Lahoz JM, Arribas JR, Guerrero A (2000) Diagnostic utility of a multiplex herpesvirus PCR assay performed with cerebrospinal fluid from human immunodeficiency virus-infected patients with neurological disorders. Journal of Clinical Microbiology 38:3061-3067.

Quinlivan M, Eugene D, Fergus R, Sean A, Ann C (2005) Real-Time Reverse Transcription PCR for Detection and Quantitative Analysis of Equine Influenza Virus. Journal of Clinical Microbiology 43 : 5055-5057.

Rakhshandehroo E, Sharifiyazdi H, Shayegh H, Ahmadi A (2014) Molecular and morphological comparison of two different types of Habronema muscae (Nematoda: Habronematidae) in horse. Parasitological Research 113 : 4439-4445. DOI: 10.1007/s00436-014-4123-2

Read SJ, Kurtz JB (1999) Laboratory diagnosis of common viral infections of the central nervous system by using a single multiplex PCR screening assay. Journal of Clinical Microbiology 37:1352-1355.

Rodriguez-Sanchez B, Jovita FP, Corinne S, Stephan Z, Sandor B, Marisa A, Jose M, Sanchez-Vizcainoa (2008) Novel gel-based and real-time PCR assays for the improved detection of African horse sickness virus. Journal of Virological Methods 151:87. DOI: 10.1016/j.jviromet.2008.03.029

Rudolph JA, Spier SJ, Byrns G, Rojas CV, Bernoco D, Hoffman EP (1992) Periodic paralysis in quarter horses: a sodium channel mutation disseminated by selective breeding. Nature Genetics 2 :144-147. DOI: 10.1038/ng1092-144

Sharon J, Spier DVM, Christian M, Leutenegger, Scott PC, Jenella EL, Jeannine BP, Tim EC, Judy E, Mihalyi BS, John EM (2004) Use of a real-time polymerase chain reaction-based fluorogenic 5' nuclease assay to evaluate insect vectors of Corynebacterium pseudotuberculosis infections in horses. American Journal of Veterinary Research 65: 829-834.

Shinwari MW, Annand EJ, Driver L, Warrilow D, Harrower B, Allcock RJ, Pukallus D, Harper J, Bingham J, Kung N, Diallo IS (2014) Australian bat lyssavirus infection in two horses. Veterinary Microbiology 173 : 224-231. DOI: 10.1016/j.vetmic.2014.07.029

Singha H, Malik P, Goyal SK, Khurana SK, Mukhopadyaya C, Eshwara VK, Singh RK (2014) Optimization and validation of indirect ELISA using truncated TssB protein for serodiagnosis 
of glanders amongst equines. Scientific World Journal 2014: 469407. DOI: http://dx.doi.org/10.1155/2014/469407

Soutullo A, Verwimp V, Riveros M, Pauli R, Tonarelli G (2001) Design and validation of an ELISA for equine infectious anemia (EIA) diagnosis using synthetic peptides. Veterinary Microbiology $79: 111-21$.

Spier SJ, Leutenegger CM, Carroll SP, Loye JE, Pusterla JB, Carpenter TE, Mihalyi JE, Madigan JE (2004) Use of a realtime polymerase chain reaction-based fluorogenic 5' nuclease assay to evaluate insect vectors of Corynebacterium pseudotuberculosis infections in horses. American Journal of Veterinary Research 65 : 829-34.

St-Laurent G, Morin G, Archambault D (1994) Detection of equine arteritis virus following amplification of structural and nonstructural viral genes by reversetranscription-PCR. Journal of Clinical Microbiology 32 : 658-665.

Svobodova Z, Jankovicova B, Horak D, Bilkova Z (2013) DotELISA Affinity Test: An Easy, Low-Cost Method to Estimate Binding Activity of Monoclonal Antibodies. Journal of Analytical Bioanalytical Techniques 4:3.

Taniguchi A, Fukushi H, Matsumura T, Yanai T, Masegi T, Hirai K (2000) Pathogenicity of a new neurotropic equine herpesvirus 9 (gazelle herpesvirus 1) in horses. The Journal of Veterinary Medical Science / the Japanese Society of Veterinary Science $62: 215-218$.

Tavares RG, Staggemeier R, Borges ALP, Rodrigues MT, Castelan LA, Vasconcelos J, Anschau ME, Spalding SM (2011) Molecular techniques for the study and diagnosis of parasite infection. Journal of Venomous Animals and Toxins including Tropical Diseases. 17 : 239-248.

Traversa D, RaffaellaIorio, Thomas RK, Vitaliy A, Kharchenko, Jakub G, Otranto D, Olivier AE, Sparagano (2007) New Method for Simultaneous Species-Specific Identification of Equine Strongyles (Nematoda, Strongylida) by Reverse Line Blot Hybridization. Journal of Clinical Microbiology 45 : 2937-2942. DOI:10.1128/JCM.00714-07

Tryon RC, Penedo MC, McCue ME, Valberg SJ, Mickelson JR, Famula TR, Wagner ML, Jackson M, Hamilton MJ, Nooteboom S, Bannasch DL (2009) Evaluation of allele frequencies of inherited disease genes in subgroups of American Quarter Horses. Journal of the American Veterinary Medical Association 234 :120-125. DOI: 10.2460/javma.234.1.120

Ueti MW, Guy HP, Lowell SK, Mary S, Glen AS, Donald PK (2005) Ability of the Vector Tick Boophilus microplus To Acquire and Transmit Babesia equi following Feeding on Chronically Infected Horses with Low-Level Parasitemia. Journal of Clinical Microbiology 43 : 3755-3759. DOI: 10.1128/JCM.43.8.3755-3759.2005
Ushikubo H (2004) Principle of LAMP method - A simple and rapid gene amplification method. Virus 54 : 107-12.

Van El, Cornel CG, Borry MC, Hastings P, Fellmann RJ, Hodgson F, Howard SV, Cambon-Thomsen HC, Knoppers A, Meijers-Heijboer BM, Scheffer H, Tranebjaerg H, Dondorp L, de Wert W (2013) Whole-genome sequencing in health care. Recommendations of the European Society of Human Genetics. European Journal of Human Genetics 21 : 1-5 DOI:10.1038/ejhg.2013.46. DOI: 10.1038/ejhg.2013.46

Varrasso A, Dynon K, Ficorilli N, Hartley CA, Studdert MJ, Drummer HE (2001) Identification of equine herpes viruses 1 and 4 by polymerase chain reaction. Australian Veterinary Journal 8:563-569.

Verma RD, Misra VC (1989) Research on epizootic, diagnosis and control of glanders with a view to eradicate the disease from India. Project Report. pp. 31-42. Indian Council of Agricultural Research, New Delhi.

Verma RD, Sharma JK, Venkateswaran KS, Batra HV (1990) Development of an avidin-biotin dot enzyme-linked immunosorbent assay and its comparison with other serological tests for diagnosis of glanders in equines. Veterinary Microbiology 25: 77-85.

Wagner WN, Jaret B, Haines D, Townsend HGG, Misra V (1992) Detection of equine herpesvirus and differentiation of equine herpesvirus type 1 from type 4 by the polymerase chain reaction. Canadian Journal of Microbiology 38 : 1193-1196.

Wang L, Raidal SL, Pizzirani A, Wilcox GE (2007) Detection of respiratory herpesviruses in foals and adult horses determined by nested multiplex PCR. Veterinary Microbiology 121: 18-28. DOI: 10.1016/j.vetmic.2006.11.009

Ward TL, Valberg SJ, Adelson DL, Abbey CA, Binns MM, Mickelson JR (2004) Glycogen branching enzyme (GBE1) mutation causing equine glycogen storage disease IV. Mammalian genome: Official Journal of the International Mammalian Genome Society 15 : 570-577. DOI: 10.1007/s00335-004-2369-1

Webb K, Colin B, Tihana H, Zoe H, Karen FS, Carl R, Richard JN, Andrew SW (2013) Detection of Streptococcus equi subspecies equi using a triplex qPCR assay. The Veterinary Journal 195: 300-304.

Westcott DG, King DP, Drew TW (2003) Use of an internal standard in a closed one-tube RT-PCR for the detection of equine arteritis virus RNA with fluorescent probes. Veterinary Research 34:165-176. DOI: 10.1051/vetres:2002063

Wetmur JG (1991) DNA probes: applications of the principles of nucleic acid hybridization. Critical Reviews in Biochemistry and Molecular Biology 26 : 227-259. 
Wise LN, Kappmeyer LS, Mealey RH, Knowles DP (2013)

Review of equine piroplasmosis. Internatinal Journal of Veterinary Medicne 27:1334-1346. DOI: 10.1111/jvim. 12168

Yasunaga S, Maeda K, Matsumura T (2000) Application of a type-specific enzyme-linked immunosorbent assay for equine herpesvirus types 1 and 4 (EHV-1 and -4) to horse populations inoculated with inactivated EHV-1 vaccine. Journal of Veterinary Medical Science 62:687-691.

Yasunaga S, Maeda K, Matsumura T, Kai K, Iwata H, Inoue T (1998) Diagnosis and sero-epizootiology of equine herpesvirus type 1 and type 4 infections in Japan using a type-specific ELISA. The Journal of veterinary medical science/the Japanese Society of Veterinary Science $60: 1133-7$.

Yeh J, Lee J, Park J, Seo H, Moon J, Cho I, Kim H, Yang Y, Ahn K, Kyung S, Choi I, Lee J (2012) A diagnostic algorithm to serologically differentiate west Nile virus from Japanese encephalitis virus infections and its validation in field surveillance of poultry and horse. Vector-Borne Zoonotic Diseases 12 : 372-379. DOI: 10.1089/vbz.2011.0709

Yeh J, Lee J, Park J, Seo H, Park J, Moon J, Cho I, Lee J, Park S, Song C, Choi I (2010) Fast duplex one-step reverse transcriptase PCR for rapid deferential detection of west Nile and Japanese encephalitis. Journal of Clinical Microbiology 48 : 4010-4014. DOI: 10.1128/JCM.00582-10

Yguerabide J, Yguerabide E (2001) Resonance light scattering particles as ultrasensitive labels for detection of analytes in a wide range of applications. Journal of Cellular Biochemistry 37 (Suppl.) 71-81.

Zhang J, Timoney PJ, MacLachlan NJ, McCollum WH, Balasuriya UBR (2008) Persistent equine arteritis virus infection in HeLa cells. Virology Journal 82 : 8456-8464. DOI: 10.1128/JVI.01249-08 